\title{
LA MANO EXTENDIDA: THE INTERACTION BETWEEN INTERNATIONAL LAW AND NEGOTIATION AS A STRATEGY TO END GANG WARFARE IN EL SALVADOR AND BEYOND
}

\author{
Emma Mahern* \\ I. INTRODUCTION
}

In August 2012 and again in May 2013, gang members came face-toface with government leaders and representatives of the Organization of American States (OAS). ${ }^{1}$ The gang members arrived with hundreds of weapons; they were not there to use these weapons, but rather to lay down their arms as a sign of good faith in their struggle to negotiate a lasting peace. $^{2}$

Over the past decade there has been increasing awareness of transnational gangs as a threat to regional security in the Americas. ${ }^{3}$ This led Silvia Aguilar, the El Salvadorian Vice-Minister of Justice, to say that "[d]omestic crime and its associated destabilization are now Latin America's most serious security threat." According to a 2012 report by the International Center for Migrant Human Rights, crime is now the main cause of displacement in Central America, and it is comparable to the displacement caused by civil wars in the region in the 1970s and 1980s. ${ }^{5}$ In 2011, the Geneva Declaration's Global Burden of Armed Violence Report named El Salvador the country with the world's most violent deaths. ${ }^{6}$ Transnational gangs have been linked to shocking displays of violence, drug and human trafficking, as well as extortion. The regional and domestic strategies of the countries most affected have been a blend of suppression

* Emma Mahern is a 2014 graduate of the Indiana University Robert H. McKinney School of Law.

1. Pandillas salvadorenas entregan armas como parte de una tregua: Episode 130527 (Univision Noticias broadcast May 28, 2013), archived at http://perma.cc/A9NW-8YN9.

2. Id.

3. Max G. Manwaring, A Contemporary Challenge to State Sovereignty: Gangs and Other Illicit Transnational Criminal Organizations in Central America, El Salvador, Mexico, Jamaica, AND Brazil 5 (2007), archived at http://perma.cc/U9J9-KF26.

4. Id.

5. Claire O’Niell McKleskey. Organized Crime Fueling Displacement in Central America, InSight CRIME (Oct. 17, 2012), http://www.insightcrime.org/newsbriefs/organized-crime-displacement-in-central-america, archived at http://perma.cc/BS8HZLCN.

6. Global Burden of Armed Violence 2011: Lethal Encounters, Geneva Declaration on Armed Violence And Development 6 (2011), archived at http://perma.cc/H6F8-6VNU. 
and prevention efforts with the majority of forces focused on the former. ${ }^{7}$ These efforts have not done much to substantially decrease violence, particularly in the northern triangle: Guatemala, Honduras, and El Salvador. ${ }^{8}$

However, in March 2012, El Salvador revealed a new strategy to decrease gang violence: a truce between the countries' main rival factions, Barrio 18 and Mara Salvatrucha, to cease violence and to stop recruiting at schools. ${ }^{9}$ This strategy has substantially reduced violence in the country and has won the support of El Salvador's President, the Secretary General, and the Secretary of Multidimensional Security of the Organization of American States (OAS). ${ }^{10}$ As part of this truce, the gang members laid down their arms, albeit symbolically, in August 2012 and May 2013. ${ }^{11}$ Some in the region, however, disagree with the idea of negotiating with the gangs and doubt the intentions of gang leadership. ${ }^{12}$

This Note briefly reviews the history and development of transnational gangs in Central America. It considers the connection to previous violence in the region and the effects of US immigration policy on the development of gangs. It then delves into the scope of the current problem with the relevant gang violence. This Note reviews the domestic and regional responses to the threat of transnational gangs. It examines various Mano Dura policies throughout Central America, as well as prevention programs and regional agreements and strategies. This Note reviews the available information regarding the truce and the developments that are still happening. It explores the role of the El Salvadorian government and the OAS in negotiating the truce. It also discusses the response from various countries in the region regarding negotiation as a strategy for decreasing violence.

The Note then examines the development of international law, and in particular, the ways in which it seeks to restrict and manage violence through International Humanitarian Law (IHL) and International Human Rights Law (IHRL). This Note explores the legal and political limitations of IHL and IHRL in reducing violence in conflicts such as the one in El Salvador. This Note demonstrates how El Salvador's international obligations may inhibit transitional justice and delay the humanitarian goals of the truce. Finally, the Note suggests ways that the international community can support the humanitarian goals embodied in the truce.

7. See infra Part IV.A.

8. McKleskey, supra note 5; see infra Part IV.A.

9. See infra Part V.

10. See infra Part V.

11. Pandillas salvadorenas entregan armas como parte de una tregua, supra note 1.

12. See infra Part V.B. 


\section{DEFINING TRANSNATIONAL GANGS ${ }^{13}$}

Experts continue to debate the meaning of the term "gang."14 It is generally agreed that gangs have a name, sense of identity, and some degree of organization; are made up of youth; and are involved in delinquent or criminal activity. ${ }^{15}$ Gangs are generally distinguishable from organized crime because "they typically lack the hierarchical leadership structure, capital, and manpower required to run a sophisticated criminal enterprise or to penetrate state institutions at high levels." 16

However, some gangs are more evolved than others. This has led to the classification of gangs as first-, second-, and third-generation. ${ }^{17}$ Firstgeneration gangs are turf-oriented, have loose and unsophisticated structures, and engage in opportunistic, localized criminal enterprises. ${ }^{18}$ Second-generation gangs are organized for commercial gain, have more centralized leadership, operate in a broader geographic area, and engage in drug trafficking and market protection. ${ }^{19}$ According to Max Manwaring, second-generation gangs "also use violence as political interference to negate enforcement efforts directed against them by police and other national and local security organizations. ${ }^{20}$ Third-generation gangs maintain elements of first- and second-generation activities, while a select group of members expand the gang's influence. ${ }^{21}$ Third-generation gangs expand their connections to other groups and expand their criminal activity to include "smuggling people, body parts, weapons, and cars; associated intimidation, murder, kidnapping and robbery; money laundering; home and community invasion; and other lucrative societal destabilization activities." 22 These third-generation gangs, as a consequence, may develop into sophisticated transnational criminal organizations "with ambitious economic and political agendas." ${ }^{23}$ There is some evidence that the

13. A note about terms: Gangs in Central America are referred to as pandillas or maras, and sometimes the terms are used interchangeably. This Note uses these terms interchangeably. This Note also interchangeably uses the English term gang member with the Spanish terms marero and pandillero, which have the same meaning. "[S]tudies that make a distinction between the two types of Central America gangs generally define pandillas as localized groups that have long been present in the region, and maras as a more recent phenomenon that has transnational roots." CLARE RiBANDO SEELKE, CONG. RESEARCH SERV., RL34112, GANGS In CENTRAL AMERICA 4 (2011).

14. Id.

15. Id.

16. Id.

17. MANWARING, supra note 3 , at 4.

18. MANWARING, supra note 3, at 4.

19. MANWARING, supra note 3, at 4-5.

20. MANWARING, supra note 3, at 5.

21. MANWARING, supra note 3, at 5.

22. MANWARING, supra note 3, at 5-6.

23. MANWARING, supra note 3 , at 6 . 
transnational gangs which operate in the northern triangle are making this transition. $^{24}$

\section{A. The History and Development of Central American Gangs}

In the 1970s and 1980s, the Mara Salvatrucha (MS-13) formed in the Rampart and Pico Union neighborhoods of central Los Angeles as Central Americans fled their home countries due to internal conflicts. ${ }^{25}$ After their arrival in Los Angeles, "[o]ut of a need for self-protection and to gain control of their new neighborhoods, the criminal elements of Central American newcomers, many of which had prior military and guerrilla training, took up various forms of continuing criminal conspiracies and quickly gained reputations for extreme wantonness and brutality." 26 The MS-13 quickly gained a reputation for employing unusual and violent tactics including the use of machetes in gang attacks. ${ }^{27}$ From Los Angeles, the MS-13 spread nationwide. ${ }^{28}$ "Although FBI officials have described MS-13 as a 'loosely structured street gang,' it has expanded geographically, and may pose an increasing national and regional security threat as it becomes more organized and sophisticated." 29 In 2004, the National Drug Intelligence Center reported that "the gang was increasing its coordination between chapters in Los Angeles, Washington D.C., Northern Virginia, and New York, perhaps indicating efforts to create a national command structure." 30

In the 1960s, Barrio 18 (also known as M-18, the 18th Street Gang, and Pandilla 18) was formed by Mexican immigrants in the Rampart section of Los Angeles. ${ }^{31}$ They were not accepted by existing MexicanAmerican gangs. ${ }^{32}$ It was the first Hispanic gang to accept members from all races, to recruit members from other states, and to grow its ranks by becoming one of the first multiracial, multiethnic gangs in Los Angeles. ${ }^{33}$

After the 1992 Los Angeles riots, police attributed much of the

24. MANWARING, supra note 3 , at 12 .

25. Luz E. Nagle, Criminal Gangs in Latin America: The Next Great Threat to Regional Security and Stability?, 14 Tex. Hisp. J.L. \& Pol'y 7, 10 (2008); Celinda Franco, Cong. Research Serv., RL34233, The MS-13 and 18Th Street Gangs: Emerging Transnational Gang Threats? 3-4 (2007).

26. Nagle, supra note 25, at 10.

27. FRANCO, supra note 25, at 4.

28. Nagle, supra note 25, at 11.

29. Clare Ribando, Cong. Research Serv., RS22141, Gangs in Central America 2 (2005)

30. FRANCO, supra note 25, at 4-5.

31. FRANCO, supra note 25, at 4-5.

32. FRANCO, supra note 25, at 4-5.

33. FRANCO, supra note 25, at 4; RIBANDO, supra note 29, at 2. 
violence and looting to local gangs. ${ }^{34}$ In the years following, California passed strict, new tough-on-crime laws like the "three strikes and you're out" legislation in $1994 .^{35}$ The effect of this legislation was a dramatic increase in California's prison population. ${ }^{36}$ Additionally, the US Congress passed the Illegal Immigrant Reform and Immigrant Responsibility Act (IIRIRA) of 1996, which made it easier to deport criminals. ${ }^{37}$ The combination of these legislative changes led to the deportation of thousands of convicted felons to El Salvador. "Between 2000 and 2004, an estimated 20,000 criminals were sent back to Central America." ${ }^{39}$ The proliferation of maras in Central America is attributable in large part "to a United States immigration and criminal justice policy that deports foreign-born criminal convicts back to their countries of origin following incarceration .... [F]or several years the United States has been pouring tens of thousands of criminals, including extremely violent offenders, into Central America's weakest and most failing states." 40 Until recently, rules also prohibited the US government from sharing the returnees' criminal history with the governments of their countries of origin. ${ }^{41}$ After deportation, gang members arrive in their countries of origin "as pariahs in places unfamiliar or unknown to them, unwelcome, and with no basis of support to assimilate and to stay out of trouble." ${ }^{22}$ It has been observed that a lack of strong familial connections in the region and a lack of fluency in Spanish leaves these individuals isolated and "[r]etaining their gang lifestyle can be their only means of surviving and thriving." 43

Upon return, deportees introduced California gang culture to their

34. MANWARING, supra note 3, at 16.

35. MANWARING, supra note 3, at 16. "In 1994, California legislators and voters approved a major change in the state's criminal sentencing law, (commonly known as Three Strikes and You're Out). The law was enacted as Chapter 12, Statutes of 1994 (AB 971, Jones) by the Legislature and by the electorate in Proposition 184. As its name suggests, the law requires, among other things, a minimum sentence of 25 years to life for three-time repeat offenders with multiple prior serious or violent felony convictions. The Legislature and voters passed the Three Strikes law after several high profile murders committed by exfelons raised concern that violent offenders were being released from prison only to commit new, often serious and violent, crimes in the community." A Primer: Three Strikes-The Impact after More than a Decade, Legislative AnAlyst's OfFice (Oct. 2005), http://www.lao.ca.gov/2005/3_strikes/3_strikes_102005.htm, archived at http://perma.cc/R9KQ-DX24.

36. MANWARING, supra note 3, at 16; A Primer: Three Strikes-The Impact after More than a Decade, supra note 35.

37. MANWARING, supra note 3, at 16; SEELKE, supra note 13, at 54.

38. MANWARING, supra note 3, at 16.

39. RiBANDO, supra note 29, at 2.

40. Nagle, supra note 25, at 11.

41. MANWARING, supra note 3, at 16.

42. Nagle, supra note 25, at 11.

43. Nagle, supra note 25, at 11-12. 
countries of origin, which included, drugs, extortions, car-theft rings, burglaries, and contract killings. "[Local officials] did not have the knowledge, experience, organization, or resources" to deal with these gangs. ${ }^{45}$ El Salvador is thought to have been hit the hardest by the gang problem, and is now "captive to the growing influence and violence of gangs." 46 In El Salvador, "widespread proliferation" of firearms and explosives, a result of the civil conflict in the 1980s, has given gangs easier access to weapons, thereby contributing to the gang problem. ${ }^{47}$

\section{B. Current Activity and Geographic Scope of Central American Gangs}

In the United States, mareros are concentrated in areas with large Central American populations like California, Maryland, New York, Texas, and Virginia, but have also spread to other communities like Lake Worth, Florida ${ }^{48}$ Information from a US gang survey shows "the MS-13 and M-18 gangs have an established presence in Washington, D.C.; Northern Virginia; certain cities in Maryland; Nashville, Tennessee; New York, New York; Houston, Texas; and other rural and urban areas." "mareros have a formidable criminal presence in El Salvador, Honduras, Guatemala, and Mexico," and authorities believe that mareros are operating to some extent in Canada and Europe. ${ }^{50}$

A 2007 report concluded that "MS-13 and M-18 members in the Washington, D.C. area were not [during the observed period] engaged in a systematic effort to become more involved in organized crime. . . . [T] he members' criminal activity was largely limited to petty theft and neighborhood extortion." ${ }^{51}$ However, criminal cases from the late 2000s involving MS-13 defendants "included information and testimony that gang members in Maryland were in telephone contact with other MS-13 members in cities across the country and . . . in El Salvador." 52 There is also evidence that the MS-13 share information and that clicas $^{53}$ in one area have loaned weapons to clicas in other areas. ${ }^{54}$ For example, by early 2008 , "Salvadoran police had found evidence suggesting that some MS-13 leaders jailed in El Salvador were ordering retaliatory assassinations of individuals

44. MANWARING, supra note 3, at 167.

45. MANWARING, supra note 3, at 167.

46. MANWARING, supra note 3, at 16-17.

47. RIBANDO, supra note 29 , at 2 .

48. Nagle, supra note 25, at 2 .

49. FRANCO, supra note 25, at 2.

50. Nagle, supra note 25, at 2.

51. FRANCO, supra note 25, at 8 (alteration added).

52. FRANCO, supra note 25 , at 9.

53. This term clica (also spelled clika or cliqa) is similar to the terms clique or set, as used in English-speaking gangs, and refers to a localized sub-group of a larger gang.

54. FRANCO, supra note 25, at 9. 
in Northern Virginia, as well as designing plans to unify their clicas with those in the United States." 55 Although the picture is still unclear, some researchers maintain "that the MS-13 gang in some Central American countries has characteristics of a third-generation gang." Also, "evidence suggests that these gangs are engaged in criminal enterprises normally associated with better organized and more sophisticated crime syndicates." ${ }^{, 57}$ The United Nations Office on Drugs and Crime (UNODC) "has cited country membership totals of some 10,500 in El Salvador, 36,000 in Honduras, and 14,000 in Guatemala." 58 Adam Blackwell, Secretary of Multidimensional Security for the OAS, estimated the number of mareros in El Salvador to be around 60,000 at the time of the relevant report, published in 2012. ${ }^{59}$

\section{THREAT OF TRANSNATIONAL GANGS TO DOMESTIC AND REGIONAL SECURITY}

Both Barrio 18 and MS-13 are known for their brutality, which is sometimes attributed to the groups' roots in the civil conflicts of the 1980s. ${ }^{60}$ In a 2005 interview, Frank Flores, a Los Angeles Police Officer assigned to the anti-gang unit, stated that "MS-13 gang members came from 'war-torn countries where . . killing was a regular occurrence-violence, beating people up, stabbing people, seeing people die[.] They were desensitized[.] Their readiness to commit a violent act was nothing; it was second nature." "61 Many of the acts of violence committed by mareros demonstrate this desensitization. For example, in Central America, "gang members held up passengers on city buses and burned one bus while it was

55. SEELKE, supra note 13 , at 5.

56. FRANCO, supra note 25, at 5 (alteration in original); see also SEELKE, supra note 13, at 4 .

57. FRANCO, supra note 25 , at 1.

58. SEELKE, supra note 13 , at 5.

59. José Luis Sanz, Adam Blackwell, secretario de seguridad multidimensional OEA: "No creo que hubiera otra opción que dialogar con las pandillas", EL FARO (Oct. 1, 2012), http://www.elfaro.net/es/201209/noticias/9804/\#.UGxorFha3Ns.email, archived at http://perma.cc/A8G4-LS7Y.

60. Nagle, supra note 25, at 10-11.

61. Nagle, supra note 25, at 10-11. According to the document released by the leaders of M-18 and MS-13 regarding the truce, "No one can object that we too are Salvadorians and that we are a social byproduct of the horrible socio-economic policies derived from the models that have been implemented in El Salvador for many years, including sending us to war in the 1980s, a war that we are considered sons of, because the majority of our members lost our fathers in this conflict, others of us are members of homes ripped apart by the effects of the emigration of our fathers and ourselves, to other countries and by the uprooting of being displaced from our places of origin." Los Voceros Nacionales de la Mara Salvatrucha MSX3 y Pandilla 18, archived at http://perma.cc/B4WH-VDBF [hereinafter Voceros] (translated by the author). 
filled with riders." ${ }^{, 62}$ In 2009, gang members allegedly killed 146 Guatemalan bus drivers. ${ }^{63}$

The level of violence in Central America, and specifically El Salvador, is astounding. According to the Geneva Declaration's 2011 Global Burden of Armed Violence report, El Salvador had more violent deaths per capita than any other country between 2004 and 2009 (the listing includes countries considered active combat zones during this period such as Iraq) ${ }^{64}$ While the average homicide rate for the world between 2000 and 2008 was nine per 100,000 inhabitants, the rates in Central America soared to fifty-two, forty-eight, and fifty-eight, for El Salvador, Guatemala, and Honduras respectively in 2008. ${ }^{65}$ The Inter-American Development Bank has estimated that in Latin America, violence costs approximately 14.2 percent of gross domestic product. $^{66}$ It is hard to say exactly what percentage of this violence is gang related. While Salvadoran police estimate that at least 60 percent of murders committed in 2004 were gangrelated ${ }^{67}$ experts argue "although gangs may be more visible than other criminal groups, gang violence is only one part of a broad spectrum of violence in Central America." ${ }^{, 68}$

Various sources indicate that MS-13 and M-18 are involved in a variety of other criminal enterprises and are connected with various organized criminal elements. The increased intensity of the War on Drugs in Mexico has reportedly led traffickers to use Central America as a transshipment point for US-bound Andean cocaine, with at least 42 percent of that US-bound cocaine stopping in Central America. ${ }^{69}$ In part of MS-13's and M-18's criminal network that includes connections throughout the region and in Spain, El Salvador has become a major transshipment point for drug trafficking and human smuggling. ${ }^{70}$ Some gang members even serve as "foot soldiers" for more organized drug trafficking organizations in Mexico. ${ }^{71}$ The gangs have grown their criminal activities to include: drug and weapons smuggling and distribution, human trafficking and prostitution, kidnapping, assassinations for hire, extortion, protection

62. Randal C. Archibold, Gangs' Truce Buys El Salvador a Tenuous Peace, N.Y. TIMES (Aug. 27, 2012), http://www.nytimes.com/2012/08/28/world/americas/in-el-salvador-gangtruce-brings-tenuous-peace.html, http://perma.cc/L5WV-BBRW.

63. SEELKe, supra note 13, at 6.

64. Global Burden of Armed Violence 2011: Lethal Encounters, supra note 6, at 6.

65. SEELKE, supra note 13 , at 2.

66. MANWARING, supra note 3, at 15.

67. RIBANDO, supra note 29 , at 1.

68. SEELKE, supra note 13, at 5.

69. SEELKE, supra note 13, at 3.

70. Nagle, supra note 25, at 16.

71. Archibold, supra note 62. 
racketeering, and larceny. ${ }^{72}$

Although there has been some concern that terrorist groups, like alQaeda, could use transnational gangs to gain access to the United States, there does not, at the time of this Note's writing, seem to be any evidence to suggest such a connection. ${ }^{73}$ In fact, "analysts have found no links between Central American gangs and Al Qaeda or other terrorist groups." ${ }^{, 74}$ But still, some researchers assert that the MS-13 gang and terrorist groups are similar in that they both have "a propensity for indiscriminate violence, intimidation, [and] coercion [that] transcend[s] borders, and target[s] nation-states." 75

The parallels between the operations of transnational gangs and terrorist organizations not only leads some to fear the potential for future collaboration, but also raises an important question about what tactics should be used to combat the violence. Some say that the growth of the transnational gangs "poses a significant concern for long-term security and stability in our hemisphere," of an autonomous quasi-fighting force capable of carrying out unspeakable violence against civil societies in the Americas." ${ }^{, 77}$ Because of membership numbers in the tens of thousands and their military grade weapons, "the two gangs are virtual armies that have the power to affect the security of the entire region." ${ }^{, 78}$ Some predict a shift in the status of gangs from "being a scourge of civil society to becom[ing] a serious paramilitary threat to national and regional security, prompting a military response to deteriorating socio-political conditions."

It has been argued that "[1]ike the United States' so-called War against Terror, there may come a point where strong and decisive military measures are necessary to isolate Central America's mareros from their sources of sustenance, namely their counterparts in the United States and other non-Latin American [S]tates where marero incursions have occurred." ${ }^{, 80}$ Such military action precipitates an "unconventional type of conflict [that] pits nonstate actors (gangs, warlords, drug barons, and/or insurgents) directly against nation-states and requires a relatively effective defense (military) capability." ${ }^{\prime 81}$ There are five operational-level national security challenges associated with the transnational gang phenomenon: 1)

72. Nagle, supra note 25, at 11; RIBANDO, supra note 29, at 1 .

73. FRANCO, supra note 25, at 2.

74. SEELKE, supra note 13 , at 6.

75. FRANCO, supra note 25, at 4 (alterations added).

76. Nagle, supra note 25 , at 8.

77. Nagle, supra note 25, at 17.

78. Archibold, supra note 62.

79. Nagle, supra note 25, at 24 (alteration added).

80. Nagle, supra note 25, at 25 (alteration added).

81. MANWARING, supra note 3 , at 10 (alteration added). 
gangs strain government resources, such as police and legal systems; 2) in areas where the government's ability to provide for the public good is challenged by internal corruption, gangs are able to challenge the legitimacy of the state; 3 ) gangs act in place of the state in ungoverned areas; 4) gangs use violence and coercion and government corruption to gain unfair economic advantages over legitimate businesses and dominate the informal economy; and 5) gangs infiltrate police and NGOs to further their goals. ${ }^{82}$

Accordingly, such conflicts have "no formal declarations or terminations of conflict; no easily identified human foe to attack and defeat; no specific territory to take and hold; no single credible government or political actor with which to deal; and no guarantee that any agreement between or among contending protagonists will be honored" relegating everyone, everywhere, part of the "battle space." 83

\section{IV. “TRADitionAL” RESPONSES to TRANSNATIONAL GANGS}

\section{A. Domestic Approaches: Mano Dura y Mano Amiga}

In the mid-2000s, El Salvador, Guatemala, and Honduras cracked down on gangs in a set of programs collectively called Mano Dura (which translates to the firm hand or heavy-handed), a program the effectiveness of which has been called into question. ${ }^{84}$ Since then, countries have also incorporated more preventative tactics often termed Mano Amiga (which translates to the friendly hand). ${ }^{85}$ Mano Dura approaches usually increased sentences for "gang membership or gang-related crime" and involved the mass incarceration of youth for illicit association. ${ }^{86}$ However, "[o]ne expert found that homicides committed by young people in the three nations increased by forty percent after the new policies were put into place." ${ }^{.87}$ These policies have played out differently in different countries. ${ }^{88}$

\section{Honduras}

In 2003, Honduras passed legislation establishing a maximum twelveyear prison sentence for gang membership and increased that penalty to thirty years in $2004 .{ }^{89}$ Honduras, which only has around 8,000 police

\footnotetext{
82. MANWARING, supra note 3, at 10.

83. MANWARING, supra note 3 , at 8.

84. Nagle, supra note 25, at 14; SEELKE, supra note 13, at 7.

85. MANWARING, supra note 3, at 21-22.

86. SEELKE, supra note 13 , at 10 .

87. Nagle, supra note 25, at 14.

88. Nagle, supra note 25, at 14.

89. RIBANDO, supra note 29 , at 3.
} 
officers (the lowest per-capita ratio in Latin America), in 2002 and 2006 attempted to combine military, police, and private armed security forces in an attempt to reduce gang violence. ${ }^{90}$ Although the crackdown initially reduced crime (an 80-percent decline in kidnapping and a 60-percent decline in youth gang violence) and was popular among the people, it raised human rights concerns. ${ }^{91}$

The US State Department's February 2005 Human Rights Report said that "death squads" had been formed to target youth gang members; in March 2005, the Honduran government announced an investigation into the allegations. ${ }^{92}$ There are also concerns about prison overcrowding. ${ }^{93}$ In May 2004, 104 inmates, many of them gang members, died in a fire in the San Pedro Sula prison. ${ }^{94}$ In February 2012, more than 300 inmates perished in a fire at the Comayagua prison. ${ }^{95}$

\section{El Salvador}

In 2003, El Salvador's Congress passed its first Mano Dura law, but it was later declared unconstitutional by the Supreme Court of Justice in 2004. ${ }^{96}$ In July 2004, El Salvador's Congress unanimously approved President Tony Saca's Super Mano Dura anti-gang legislation, which included "reforms stiffening the penalty for gang membership to up to five years in prison and for gang leadership to nine years." 97 In February 2005, El Salvador's Legislative Assembly restricted gun ownership, especially for youths, to enhance Mano Dura measures ${ }^{98}$ "and began a complementary effort of prevention and rehabilitation called Mano Amiga." "W9 While these laws provided some protections for accused minors, it also enhanced police power to search and arrest gang members. ${ }^{100}$ At first, it appeared the reforms were working. Approximately 60,000 young Salvadorans were incarcerated during the first three years of the program ${ }^{101}$ "including some

90. Nagle, supra note 25, at 14.

91. RIBANDO, supra note 29, at 3.

92. Ley Anti-Maras [“Anti-Gangs Act”], No. 158/2003, art. 49 (2003) (El Sal.); RiBANDO, supra note 29, at 3.

93. RIBANDO, supra note 29 , at 3.

94. RiBANDO, supra note 29 , at 3.

95. Mariano Castillo \& Elvin Sandoval, More than 300 Killed in Honduras Prison Fire, CNN (Feb. 16, 2012, 1:15 AM), http://www.cnn.com/2012/02/15/world/americas/hondurasfire-deaths/index.html, archived at http://perma.cc/8HA2-ULKL.

96. SEELKE, supra note 13, at 10.

97. RIBANDO, supra note 29, at 3; see also SEELKE, supra note 13, at 10.

98. RIBANDO, supra note 29 , at 3

99. MANWARING, supra note 3, at 21-22.

100. SEELKE, supra note 13 , at 10.

101. Nagle, supra note 25, at 15. 
14,000 youth in El Salvador between mid-2004 and late 2005,"102 and "[t]he Salvadoran government reported that the gang legislation led to a fourteen percent drop in murders in 2004."

However, early benefits of Mano Dura turned to disappointments, with an estimated 10,000 of 14,000 suspects arrested in 2005 being released due to lack of evidence. ${ }^{104}$ Some wrongly accused youth joined gangs while in prison. ${ }^{105}$ In 2006, the Salvadoran Research Foundation for the Application of the Law found that Mano Dura policies had "actually increased gang-related violence, and ha[d] further eroded public confidence in the PNC [Salvadorian Police force], which [was] increasingly viewed as an inherent violator of human rights."106 The United Nations, concerned about possible human rights abuses, said that "the tough measures only strengthened the gangs' resolve and forced continuing criminal enterprises and acts of violence, such as burglary, kidnapping, and recently, massive extortion, to be directed from within prison walls."107 Non-profit organizations in El Salvador have asked that the government turn its attention away from Mano Dura policies and toward the rehabilitation of gang members. ${ }^{108}$ The overcrowding in prisons and the resulting inter-gang violence led to the death of many inmates. ${ }^{109}$ There are also reports of extrajudicial killings of youth, especially suspected gang members, or recent returnees, by groups of vigilantes. ${ }^{110}$ These attacks are noted by the leaders of MS-13 and M-18 in the document they released regarding the truce, which pled the request "that [members] aren't discriminated against and that we aren't oppressed for the simple fact that we are tattooed, without having committed any type of crime." "111 Ex-gang members report that employers will not hire them. ${ }^{112}$ In response to Mano Dura, gangs have changed their behavior, such as avoiding visible tattooing, to avoid detection. ${ }^{113}$ The new president of El Salvador, Mauricio Funes, "has increased funding for prevention programs to roughly $14 \%$ of the Ministry of Security's budget (from a historic average of just over 1\%)."114

102. SEELKE, supra note 13 , at 11.

103. RIBANDO, supra note 29 , at 3.

104. SEELKE, supra note 13, at 11.

105. SEELKE, supra note 13, at 11.

106. Nagle, supra note 25, at 15 (internal quotation marks omitted) (alterations added).

107. Nagle, supra note 25, at 15.

108. RIBANDO, supra note 29, at 3-4.

109. SEELKE, supra note 13 , at 8.

110. SEELKE, supra note 13, at 11.

111. Voceros, supra note 61 (translated by the author).

112. SEELKE, supra note 13 , at 7.

113. SEELKE, supra note 13 , at 7.

114. SEELKE, supra note 13, at 12. 


\section{Other Countries' Initiatives}

Panamanian President Martin Torrijos initiated Mano Amiga in September $2004 .{ }^{115}$ It provides "positive alternatives," like theatre or sports, to gangs for at-risk youth aged fourteen to seventeen. ${ }^{116}$ The program is supported by nongovernmental organizations (NGOs) and provides services to more than 10,000 youth. ${ }^{117}$ Also, the Ministry of Social Development administers job training and rehabilitation services to former gang members. ${ }^{118}$ Panama was approved for a $\$ 22.7$ million loan by the InterAmerican Development Bank (IDB) to fund these and other programs aimed at preventing youth violence. ${ }^{119}$

Nicaragua also adopted a youth crime prevention strategy focused on family, school, and community intervention. ${ }^{120}$ The Ministry of the Interior, supported by funding from the IDB, has a program to target at-risk youth in eleven different municipalities. ${ }^{121}$ Costa Rica is also known to favor the "preventive and rehabilitation oriented approach."122

Guatemala introduced Mano Dura legislation in 2003, which never passed, but the Guatemalan government has executed "periodic law enforcement operations to round up suspected gang members." 123 Concerned about past abuses in Guatemala, many human rights organizations "oppose any measures that would strengthen law enforcement's power to fight the gangs." 124

In June 2010, Belize became the first country to try a direct approach by negotiating a safe zone truce with localized criminal gangs, in exchange for jobs programs for gang members and provides avenues for mediation of conflicts. ${ }^{125}$ At the end of 2012, Belize announced that the program would come to an end due to a lack of funding. ${ }^{126}$ Many critics of the program argued that it had strengthened the gangs by providing them with funding

\footnotetext{
115. RIBANDO, supra note 29 , at 4.

116. RIBANDO, supra note 29 , at 4.

117. RIBANDO, supra note 29 , at 4.

118. SEELKE, supra note 13, at 11.

119. SEELKE, supra note 13, at 11-12.

120. RIBANDO, supra note 29 , at 4.

121. SEELKE, supra note 13, at 11.

122. SEELKE, supra note 13, at 11-12.

123. SEELKE, supra note 13 , at 10.

124. RiBANDO, supra note 29 , at 4.

125. Mary Vasquez, Restore Belize Keeping Gang Truce with Employment for 200, ChanNel5Belize.COM (May 2, 2012), http://edition.channel5belize.com/archives/69903, archived at http://perma.cc/UR26-MVP3.

126. Jeremy McDermott, Money Runs Out for Belize Gang Truce, InSight CRIME (Dec. 24, 2012), http://www.insightcrime.org/news-briefs/money-runs-out-for-belize-gang-truce, archived at http://perma.cc/55MP-82AF.
} 
and had done little to prevent violence in the long term. ${ }^{127}$

\section{B. Multilateral/Regional Approaches: Suppression and Prevention}

There have been a number of regional, bilateral, and multilateral measures to address the issues presented by transnational gangs. In March 2005, the presidents of El Salvador and Guatemala agreed to set up a joint security force to address gang activity along their border. ${ }^{128}$ In April 2005, at a meeting in Honduras, Central American heads of state discussed "coordinating security and information-sharing initiatives to fight the gangs." 129 Another regional example includes the signing of a multilateral agreement by Belize, Guatemala, and Mexico to combat "narco-terrorism and criminal gangs." 130

\section{US Efforts}

The United States has worked to build several bilateral or multilateral solutions to the gang problem on the North American continent. In 2004, the FBI established an MS-13 National Gang Task Force to coordinate local, state, and federal investigations. ${ }^{131}$ On February 23, 2005, it announced the creation of a liaison office in San Salvador to coordinate regional information-sharing and anti-gang efforts. ${ }^{132}$ In October 2007, the Bush Administration proposed the Mérida Initiative, an anti-crime and counterdrug program for Mexico and Central America. ${ }^{133}$

In 2010, the funding from the Merida Initiative - Central America was directed into a separate program, the Central America Regional Security Initiative (CARSI). ${ }^{134}$ The primary goals of CARSI are:

1. Create safe streets for the citizens in the region; 2. Disrupt the movement of criminals and contraband within and between the nations of Central America; 3. Support the development of strong, capable, and accountable Central American governments; 4. Re-establish effective state presence and security in communities at risk; and, 5. Foster enhanced levels of security and rule of law coordination

127. Id.

128. RIBANDO, supra note 29 , at 4.

129. RIBANDO, supra note 29 , at 4.

130. MANWARING, supra note 3, at 15 (internal quotation marks omitted).

131. FRANCO, supra note 25, at 12.

132. RIBANDO, supra note 29 , at 5.

133. SEELKE, supra note 13, at 15.

134. SEELKE, supra note 13 , at 15. 
and cooperation between the nations of the region. ${ }^{135}$

From 2008 to 2011, the United States gave \$361.5 million to Central America via the Merida Initiative and CARSI. ${ }^{136}$ For fiscal year 2012, Congress approved an additional \$105 million for CARSI. ${ }^{137}$ Although the idea behind CARSI was to combine suppressive and preventative measures, "the majority of the money . . . is allocated for security forces," which comprises 73 percent, and not social programs (only 27 percent of funds). ${ }^{138}$

The US State Department also offers the International Law Enforcement Academy (ILEA) in San Salvador, which provides training and assistance to Central American law enforcement officials, and "established a model police precinct in Villanueva, Guatemala."139 "In January 2008, INL sent a Regional Gang Advisor to El Salvador to coordinate its Central American gang programs." International Development (USAID) has funded several programs including one program in partnership with the Central American Integration System (SICA), the Regional Youth Alliance USAID-SICA, which seeks to provide funding to NGOs in targeted communities to support community leaders and youth programs, along with other preventative programming. ${ }^{141}$

\section{The Role of Intergovernmental Organizations}

Several Intergovernmental Organizations have addressed the issues related to transnational gangs in Central America. SICA has allowed Central American leaders and officials to meet regularly, "often accompanied by their U.S. and Mexican counterparts, to discuss ways to

135. SEELKE, supra note 13, at 15-16.

136. Central American Regional Security Initiative (CARSI), InSight CRIME (Oct. 18, 2011), http://www.insightcrime.org/security/central-america-regional-security-initiative, archived at $\mathrm{http}: / /$ perma.cc/E8HT-AVGC.

137. Id.

138. Id. Key programs funded through CARSI/Merida Initiative include: Central American Fingerprinting Exploitation (CAFÉ) ("a criminal file/fingerprint initiative that has incorporated thousands of finger prints from gang members from Mexico, El Salvador, Belize, Honduras, and Guatemala"); Transnational Anti-Gang (TAG) Units (a program that creates "vetted police units that work with FBI agents stationed in San Salvador on investigateing gang-related cases"); Central American Law Enforcement Exchange (CALEE) ("a joint FBI/[International Narcotics and Law Enforcement Affairs] program that brings together law enforcement officials from Central America and from several large US cities to share information"); and Repatriation-Criminal History Information Program (CHIP) (a joint FBI/ [U.S. Immigration and Customs Enforcement (ICE)] program to provide more complete criminal history information on US deportees to Central American law enforcement officials"). SEELKE, supra note 13, at 18.

139. SEELKE, supra note 13, at 17.

140. SEELKE, supra note 13, at 17.

141. SEELKE, supra note 13, at 18-19. 
coordinate security and information sharing" regarding gangs. ${ }^{142}$ This cooperation led to a regional security plan that was adopted in $2007 .{ }^{143} \mathrm{In}$ the plan, the leaders agreed "to designate transnational gang liaison offices in each country" to collect and share information, conduct investigations, and build a regional database on gangs. ${ }^{144}$

On June 5, 2007, the OAS General Assembly passed a resolution to "promote hemispheric cooperation in dealing with criminal gangs;" then on January 12, 2008, the OAS Permanent Council held a special session about the problem of gangs. ${ }^{145} \mathrm{~A}$ "Regional Strategy to Promote Inter-American Cooperation in Dealing with Criminal Gangs" was developed by the Working Group to Prepare a Regional Strategy to Promote Inter-American Cooperation in Dealing with Criminal Gangs. ${ }^{146}$

Formed in 2000, the Inter-American Coalition for the Prevention of Violence (IACPV) is a multilateral group that promotes preventative means of combating crime and gangs in the region, but the group has been relatively inactive in recent years. ${ }^{147}$

The United Nations Development Programme (UNDP) "has supported small arms control; police reform; violence reduction; and disarmament, demobilization, and reintegration programs in Central America," and "conducted research projects on the costs of violence in particular countries and published a comprehensive regional study on security challenges facing Central America." 148 Also, UNODC has highlighted the role of transnational gangs in the Americas in several reports. ${ }^{149}$

\section{The Peace Process in El Salvador: A NeW APproach to DECREASING VIOLENCE}

In spite of a multitude of domestic and regional efforts to suppress gang activity and to prevent gang membership, the homicide rate in El Salvador increased from forty per 100,000 inhabitants at the inception of Mano Dura in 2003, to fifty-two per 100,000 inhabitants in $2008 .{ }^{150}$ In

142. SEELKE, supra note 13 , at 13.

143. SEELKE, supra note 13 , at 13.

144. SEELKE, supra note 13, at 13.

145. SEELKE, supra note 13, at 14.

146. SEELKE, supra note 13, at 14; Permanent Council of the Org. of American States Draft Res., Regional Strategy to Promote Inter-American Cooperation in Dealing with Criminal Gangs, OEA/Ser.G CSH/GT/PD-35/10 rev. 3 (May 11, 2010).

147. Id.

148. Id.

149. E.g., U.N. Office of Drugs \& Crime, Transnational Organized Crime in Central America And the CARibBeAn: A ThreAt Assessment 21-30 (2012), archived at http://perma.cc/BW9U-W2MY.

150. See SEELKE, supra note 13, at 2. 
March of 2012, mediators held a press conference to announce that El Salvador's two largest gangs, MS-13 and M-18, had reached a truce. ${ }^{151}$ The truce was negotiated between gang leaders from the two groups in prison with the help of mediators Raúl Mijango, a former lawmaker, and Msgr. Fabio Colindres, the military chaplain. ${ }^{152}$ By March, the two groups had made arrangements to call an end to violence and the recruiting of children. ${ }^{153}$ At first, the government was reluctant to acknowledge its part in the negotiations, but eventually it became clear that the Security Ministry had been involved in the negotiations and that the truce was, to some degree, aided by the government's agreement to move several prisoners to less restrictive facilities. ${ }^{154}$ According to the Salvadorian Security Ministry, the truce led to a 32 percent drop in homicides in the first half of 2012, a 50 percent reduction in kidnappings, and a 10 percent decline in extortion. ${ }^{155}$ According to official national police statistics, the number of homicides decreased 41 percent in 2012 compared to 2011 . $^{156}$ "The truce period also brought about El Salvador's first day free of murder in three years."157

After announcing the truce, Raul Mijango released a document, later authenticated by gang members, stating the position of the gangs. ${ }^{158}$ The document says that the group does not "wish to keep making war," and that

Since last year we have begun internally a deep process of reflection and analysis of the serious and pressing problems facing our country, of which we have been part . . . after 20 years we have been able to reach an agreement between the two rival gangs where we have managed . . . to significantly reduce the murders in the country, and, in a gesture of goodwill, to cancel all actions that include attacks against soldiers, police and guards. ${ }^{159}$

The document also made it clear that the leaders consider this process

151. Sanz, supra note 59.

152. See Archibold, supra note 62.

153. Archibold, supra note 62.

154. Archibold, supra note 62.

155. Archibold, supra note 62.

156. Edward Fox, El Salvador Homicides Fell over 40\% in 2012, InSight CRIME (Jan. 4, 2013), http://www.insightcrime.org/news-briefs/el-salvador-homicides-fell-over-40-percent2012, archived at $\mathrm{http}: / /$ perma.cc/9FZJ-7GQP.

157. Patrick Corcoran, Do El Salvador Killings Reflect Danger to the Gangland Truce?, INSight CRIME (Aug. 23, 2012), http://www.insightcrime.org/news-analysis/el-salvadormara-salvatrucha-killings-truce-gangs, http://perma.cc/K5EU-LNVW.

158. Hannah Stone, El Salvador Gangs Confirm Truce, InSight CRime (Mar. 23, 2012), http://www.insightcrime.org/news-briefs/el-salvador-gangs-confirm-truce, http://perma.cc/9EWV-2H9V.

159. Id. 
one that is not just about cessation of violence, but one that is also about solving some of the lingering social problems which push their members into violent lifestyles:

We are people who play with life, principally with our own lives because we have nothing to lose .... It is necessary to understand once and for all that we are a social phenomenon and that the war that we have seen ourselves as obligated to fight has socioeconomic causes and more than anything its solutions is not only legal and by repression, but also by social and economic means. ${ }^{160}$

They also asked for the support of Salvadorians generally: "Give us the opportunity, support our guides, and don't give credit to obtuse positions that as in the past, always opposed and boycotted rational and peaceful solutions and provoked the extension of a conflict that caused tens of thousands of deaths." 161 The truce has been compared by some gang members to the one that halted the twelve-year civil war in $1992 .{ }^{162}$ Ludwig Rivera, a Barrio 18 leader, said: "It's not that the truce is weak. We feel it is strong. But the lack of involvement of the authorities and the public could make it weak. They all think we are animals, but we have rights and we are taking a step, so they should take a step."163

\section{A. Phase Two: Peace Zones}

In November 2012, the mediators of the negotiations in El Salvador announced a second phase of the truce that would establish peace zones, where particular municipalities would be designated as "special zones of peace" with gangs agreeing to non-aggression and a stop to extortion, kidnapping, theft, and murder. ${ }^{164}$ According to the negotiators' proposal, these peace zones would include the following: a non-aggression pact between gangs; an obligation to reduce and eradicate criminal activity including extortion; a voluntary disarmament of gangs; the establishment of community collectives made up of gang members that would work on development in the community; a delegation of Policía Nacional Civil (PNC) consisting mostly of community police; an end to the police tactics of gang roundups and night raids and to policies that criminalize gang

160. Voceros, supra note 61 (translated by the author).

161. Archibold, supra note 62.

162. Archibold, supra note 62.

163. Archibold, supra note 62.

164. Hanna Stone, Next Phase of El Salvador Gang Truce: Peace Zones, InSIGHT CRIME (Nov. 23, 2012), http://www.insightcrime.org/news-briefs/next-phase-salvador-gang-trucepeace-zones, archived at http://perma.cc/Q3KG-5RBW. 
identity; cooperation between government and business to improve the job market for youth, including gang members that have left behind crime; a prioritization of mental health campaigns and cultural education by the government; and a local citizen crime-watch. ${ }^{165}$ In early December 2012, the leaders of MS-13, Barrio 18, and three smaller street gangs (Mao Mao, Mirada Locos, and La Maquina) agreed to the terms of the proposal, submitted a list of ten municipalities where they would be willing to have peace zones and ordered members in those cities to begin disarming. ${ }^{166}$ However, President Funes refused to accept the terms of the proposal, which included a repeal of the 2009 anti-mara law, and an end to night raids. ${ }^{167}$ While defending the 2009 anti-mara law as a "valid instrument of the law, which has shown efficacy," he also said that it could be made more "efficient," leaving the door open for further negotiations about the amendment of the statute. ${ }^{168}$ In January, the first Peace Zone was instituted in Ilopango, a town near the capital. ${ }^{169}$ In February, Defense Minister Alito Benitez announced that the military would also withdraw from peace zones, so that they could focus on crime in other areas. ${ }^{170}$

While the peace zone program appeared to be working, the truce has not completely stopped the violence in these communities. In September 2013, in Ilopango, four members of the Barrio 18 were killed while gang leadership met for peace talks nearby. ${ }^{171}$ The leaders of MS-13 and Barrio 18 , along with the mayor of Ilopango all claimed that the murders were not carried out by gang members but rather by those who wished to undermine

165. Fabio Colindres \& Raul Mijango, Pronunciamiento a la Nación, (Nov. 22, 2012), http://www.lapagina.com.sv/userfiles/image/Ernesto\%20V\%C3\%A1squez/ZU1860.jpg, archived at http://perma.cc/57SD-V44U (translated by the author).

166. Elyssa Pachico, El Salvador Gangs Accept Proposal to Create 'Peace Zones', InSIGHT CRIME (Dec. 5, 2012), http://www.insightcrime.org/news-briefs/el-salvador-gangsaccept-peace-zones, http://perma.cc/8P8J-QQE9; Los Voceros Nacionales de las Pandillas: MSX3, Barrio 18, Mao-Mao, Maquina y Mirada Locos; A Los Facilitadores del Proceso de Tregua y de Paz, al Pueblo Salvadoreño y demas Pueblos del Mundo (2012), archived at http://perma.cc/3M9S-PFMB (translated by the author).

167. James Bargent, El Salvador President Open to Reform But Not Repeal of Anti-Gang Law, INSIGHT CRIME (Dec. 18, 2012), http://www.insightcrime.org/news-briefs/el-salvadorfunes-repeal-anti-gang-law, http://perma.cc/8M4B-GD3V.

168. Id.

169. Miriam Wells, El Salvador 'Peace Zone' Launched in Second Phase of Gang Truce, INSight CRIME (Jan. 23, 2013), http:/www.insightcrime.org/news-analysis/el-salvadorpeace-zone-launched-in-second-phase-of-gang-truce, archived at http://perma.cc/958CMSDV.

170. Elyssa Pachico, Military to Withdraw from El Salvador 'Peace Zones', InSight CRIME (Feb. 4, 2013), http://www.insightcrime.org/news-briefs/military-to-withdraw-fromel-salvador-peace-zones, archived at http://perma.cc/D4B9-NZ6U.

171. Charles Parkison, El Salvador Gang Truce Shaken by 'Peace Zone' Murders, INSIGHT CRIME (Sept. 9, 2013), http://www.insightcrime.org/news-briefs/el-salvador-gangtruce-rocked-by-peace-zone-murders, archived at http://perma.cc/6E7A-ETEU. 
the truce - even suggesting that perhaps the murders had been executed by Salvadorian security forces. ${ }^{172}$ Salvadorian police denied this claim. ${ }^{173}$ Regardless of who was responsible, these events have "cast a shadow" over the peace process. ${ }^{174}$

\section{B. Strain on the Truce}

These "shadows" have haunted the peace process in El Salvador from the beginning, with critics citing continued violence and extortion as signs of bad faith negotiation by the gangs and as signals that the truce is a sham. ${ }^{175}$ The truce has not totally stopped violence among gang members. In September 2012, two bosses of MS-13 were killed by underlings who sought to enforce the truce by preventing the bosses from killing rival gang members. ${ }^{176}$ Critics of the gang truce have also claimed that some murders have been in retaliation against those in El Salvador who have spoken out against the truce. ${ }^{177}$ According to a recent report by the International Assessment and Strategy Center, gang members who opposed the truce may have been murdered to silence dissent. ${ }^{178}$ Critics explain the lower homicide rate has not resulted from an actual reduction in violence, but a shift from open killing in the street to "disappearance." 179 These accusations are difficult to substantiate because of the government's poor tracking of statistics in cases of disappearance. ${ }^{180}$ However, such theories have been supported recently by the increase in the number of mass graves, and the number of reported disappearances in the first months of 2013. ${ }^{181}$ However,

172. $I d$.

173. Id.

174. Id.

175. See id; James Nye, Inside El Salvador's Secretive Prison Pits Where Notorious Gangs are Crammed Together like Livestock in Cells the Size of a Shed, DAILY MAIL (Aug. 29, 2013), http://www.dailymail.co.uk/news/article-2405792/Inside-secretive-prison-pits-ElSalvadors-notorious-gangs-crammed-like-livestock.html, archived at http://perma.cc/MTP422HS.

176. Corcoran, supra note 157.

177. Marguerite Cawley, Opponents of El Salvador Gang Truce Facing Payback Killings, InSight CRIME (Mar. 6, 2013), http://www.insightcrime.org/newsbriefs/opponents-of-el-salvador-gang-truce-facing-pay-back-killings, archived at http://perma.cc/5KKD-HPCJ; Douglas Farah \& Pamela Phillips Lum, Central american Gangs and Transnational Criminal Organizations: The Changing RELATIONSHIPS IN A TIME OF TURMOIL 25 (2013), archived at http://perma.cc/MN5L-TR6K.

178. Marguerite Cawley, supra.

179. Hannah Stone, The Murky Question of Disappearance in El Salvador: An El Faro Investigation, INSIGHT CRIME (Jan. 25, 2013), http://www.insightcrime.org/newsanalysis/the-murky-question-of-disappearances-in-el-salvador-an-el-faro-investigation, archived at http://perma.cc/E2ZY-URWE.

180. Id.

181. James Bargent, Disappearances, Clandestine Graves on the Rise in El Salvador, 
it is difficult to tell if this is due to an actual increase or an improvement in the government's tracking methods made under political pressure of those opposed to the truce. ${ }^{182}$ A recent analysis of data regarding gang violence in individual municipalities in El Salvador illustrates the complexities in understanding the reduction in violence in El Salvador. ${ }^{183}$ This data shows that while homicides have decreased overall, they have increased in 30 percent of municipalities. ${ }^{184}$ Another recent development is that a higher percentage of homicides are now being attributed to gangs, although the methods for attributing homicides to gangs versus non-gangs are murky. ${ }^{185}$ However, it is important to recall that the current homicide rate is still far below what it was preceding the truce. When comparing the first seven months of the truce to the second seven months of the truce, there was actually a decrease in the overall number of homicides. ${ }^{186}$ Recent reports have shown that the majority of the more than 500 weapons handed over by gangs as part of the truce were not in working order. ${ }^{187}$ Those who oppose the truce say that this is evidence of bad faith by the gangs. ${ }^{188}$

While the truce is still fully in effect, the news regarding developments throughout 2013 were mixed in large part due to the political climate in El Salvador as the presidential election approached. According to a public opinion poll conducted by La Universidad Technologica de El Salvador, 47 percent of Salvadorians believe that the gangs benefit most from the truce. ${ }^{189}$ In the same survey, only 16 percent of respondents indicated the general population benefited the most, 8.7 percent stated that the political parties benefited the most, and 13.3 percent that the government benefited most. ${ }^{190}$ Sixty-eight percent of respondents thought that the truce was for political ends, and 50 percent thought it had not

INSIGHT CRIME (Mar. 8, 2013), http://www.insightcrime.org/news-briefs/disappearancesclandestine-graves-rise-el-salvador, archived at http://perma.cc/7JN4-2MJ4.

182. Id.

183. Juan Carlos Garzon, What Does El Salvador's Homicide Distribution Say about the Gang Truce?, InSight CRIME (July 18, 2013), http://www.insightcrime.org/newsanalysis/what-does-el-salvador-homicide-distribution-say-about-the-truce, archived at http://perma.cc/X5T3-CSQ7.

184. Id.

185. Id.

186. Juan Carlos Garzon, How to Strengthen the Fragile Gang Truce in El Salvador, INSIGHT CRIME (July 18, 2013), http://www.insightcrime.org/news-analysis/el-salvadorhomicides-gang-truce-breakdown, archived at http://perma.cc/J2MX-CDDY.

187. Jeremy McDermott, Weapons Surrendered by El Salvador's Maras Useless, INSIGHT CRIME (Aug. 8, 2013), http://www.insightcrime.org/news-briefs/weaponssurrendered-el-salvador-maras-useless, archived at http://perma.cc/L3YH-6H7J.

188. Id.

189. Centro de Investigación de la Opinión Pública SAlvadoreña, Evaluación de la Tregua entre Pandillas, Resultados de la Encuesta LVIII de Opinión Publica 3 (2013), archived at $\mathrm{http}: / /$ perma.cc/N5LR-BACR.

190. Id. at 3 . 
produced any results. ${ }^{191}$ In a poll conducted by the Public Opinion Institute, when asked if the gang truce had reduced crime, 42 percent of respondents said "not at all," 30 percent said only a "little," and 10 percent responded, "a lot." " The most negative views of the truce's impact are held by "lower-middle," "working class," and "marginal" social groups. ${ }^{193}$ Additionally, an indication of the political nature of the gang truce is that "those with the most negative opinions are members of the Grand Alliance for National Unity (GANA) and the Nationalist Republican Alliance (ARENA) parties - that is to say, the opposition parties."194

Many politicians supportive of the truce have found themselves caught in the political crosshairs as election season heats up. Some government officials and legislators have criticized and demanded investigation into truce broker and former Congressman Raul Mijango. ${ }^{195}$ Additionally the El Salvadorian Attorney General has accused former Minister of Security David Munguia Payes of ordering a halt to security operations against fourteen gang structures in San Salvador as part of the truce. ${ }^{196}$ The new Security Minister, Ricardo Perdomo, has been critical of the results of the truce, citing it as a cause of expansions of narcotrafficking in the country among other concerns. ${ }^{197}$ When asked what accounts for the differences in position between himself and his predecessor, Perdomo said that it was because President Funes had instructed him to "conform to reality." 198 However, in October 2013, a former government-member-turned-opposition-party-member accused Minister Perdomo of taking actions supporting the truce-such as letting gang members leave prison to participate in a meeting of a local religious sect and to answer questions about the truce. ${ }^{199}$ Funes, nearing the end of

191. Id. at 4.

192. Encuesta de Evaluación del Cuarto AÑo de Gobierno de Mauricio Funes, Asemblea Legislativa, Y AlCAldíAs 49 (2013), archived at http://perma.cc/D97F-BWCX.

193. Garzon, supra note 186.

194. Garzon, supra note 186.

195. Marguerite Cawley, El Salvador Politicians Demand Investigation into Truce Mediator, INSIGHT CRIME (July 5, 2013), http://www.insightcrime.org/news-briefs/elsalvador-politicians-order-investigation-into-truce-mediator, archived at http://perma.cc/FR8Y-EJ54.

196. James Bargent, Ex-Minister Accused of Interfering in El Salvador Anti-Gang Ops, INSight CRIME (July 18, 2013), http://www.insightcrime.org/news-briefs/ex-ministeraccused-of-interfering-in-anti-gang-ops-in-el-salvador, archived at http://perma.cc/4MSWSSTQ.

197. Marguerite Cawley, El Salvador Gangs Using Truce to Strengthen Drug Ties: Official, InSight CRIME (July 19, 2013), http://www.insightcrime.org/news-briefs/elsalvador-gangs-using-truce-to-strengthen-drug-ties-security-minister, archived at http://perma.cc/BEJ6-YEJ6.

198. Id.

199. Charles Parkinson, Prisons Probe Sparks Political Spat over El Salvador Truce, InSight CRIME (Oct. 8, 2013) http://www.insightcrime.org/news-briefs/prisons-probe- 
his presidency, has been ambivalent about the truce, at times showing support at other times being critical. While his administration acknowledged involvement in the truce, Funes never acknowledged personal involvement. ${ }^{200}$

In May, the Constitutional Chamber of the Supreme Court of Justice removed Minister Munguia Payes from his post finding that the post should be held by a civilian. ${ }^{201}$ With the removal of Payes, the murder rate began to rise, ${ }^{202}$ leading to speculation that the gangs were responding with violence for removal of their strongest governmental ally. ${ }^{203}$ This belief was further supported by statements made by the truce broker Raul Mijango, which indicated that the increase in violence was in retaliation for restrictions placed on imprisoned gang members by new Security Minister Ricardo Perdomo. ${ }^{204}$ The gangs' official position according to a press conference and subsequent press release is that they intend to maintain the conditions of the truce if the new Security Ministry officials renew the commitments of the outgoing minister, but they warn that the Supreme Court decision "puts the security of Salvadorians at risk." 205

These new developments have led some to question the viability of the truce when the negotiating position of the gangs is based entirely on violence. Florida International University Professor of International Relations, Jose Miguel Cruz, has noted that in order for the gangs to continue to wield negotiating power, they rely on the existence of violence, which is the very thing the terms of the truce aim to eradicate. ${ }^{206}$ Others have criticized the truce because of the position it puts the government in. While gangs have agreed to reduce violence, extortion continues until they have legitimate alternatives, thus creating a catch-22 for the government: "[T]he gangs cannot be permitted to continue carrying out criminal activities, but if law enforcement continues to pursue them with the hardline 'mano dura' (iron fist) policies previously in place, it may derail the whole

sparks-political-spat-over-el-salvador-truce, archived at http://perma.cc/CY7T-EZUA.

200. Oscar Martinez, Making a Deal with Murderers, N.Y. Times (Oct. 5, 2013), http://www.nytimes.com/2013/10/06/opinion/sunday/making-a-deal-with-

murderers.html?pagewanted=all\&_r=0, archived at $\mathrm{http}: / /$ perma.cc/W6MX-6PFL.

201. Id.

202. $I d$.

203. Id.

204. Cawley, supra note 197.

205. Hector Silva Avalos \& Steve Dudley, Exit of El Salvador Security Minister Puts Truce at Risk, InSIGHT CRIME (May 20, 2013), http://www.insightcrime.org/newsanalysis/exit-of-el-salvador-security-minister-puts-gang-truce-at-risk, http://perma.cc/XU7H-QUKT.

206. Tomás Guevara, José Miguel Cruz: "Las Pandillas Son las que Mandan; Se Sienten Empoderados”, ElSALVADOR.COM (July 2013), http://www.elsalvador.com/mwedh/nota/nota_completa.asp?idArt=8027764\&idCat=47859, archived at $\mathrm{http}: / /$ perma.cc/PCS3-XULQ. 
process. $^{, 207}$

In spite of the mounting trouble surrounding the truce, the maras remain committed. According to a statement released by the gangs in September 2013, their commitment to the truce was unbreakable. ${ }^{208}$ The statement also emphasized that the mareros, who planned to vote, were watching the elections closely and evaluating each candidate's plan for public security. ${ }^{209}$

\section{Blessing of the $O A S$}

In July 2012, gang leaders sat down with José Miguel Insulza, the Secretary General of the Organization of American States. ${ }^{210} \mathrm{He}$ "called the truce a promising turn in stemming the tide of violence in Central America." ${ }^{211}$ There was also a symbolic laying down of arms. ${ }^{212}$ Insulza said, "[i]f the presence of the O.A.S. secretary general helps in this peace proposal, I will be here." ${ }^{213}$ In July 2012 Insulza announced that the O.A.S. would serve as guarantor of the peace process. ${ }^{214}$ Adam Blackwell, O.A.S. Secretary of Multidimensional Security, himself admitted to his involvement as early as December 2011 in strategic planning that ultimately brought the gangs to the table. ${ }^{215}$ In spite of criticism, Blackwell has given the truce his full support and plans to move forward with the formation of a technical committee to help formalize the process as it moves forward and to potentially produce documents and more formal agreements. ${ }^{216}$ Blackwell was also present at the laying down of arms in May $2013 .^{217}$ The OAS again evaluated the progress in the peace process in September 2013. ${ }^{218}$

\section{Reaction by States in the Region}

Countries in the region have expressed differing opinions about the

207. Bargent, supra note 196.

208. Voceros Nacionales de las Pandillas: MSX3, Barrio 18, Mao-Mao, Maquina, Mirada Locos 13, Retirados y Los Privados y Privadas de Libertad de Origen Comun. Comunicado (Sept. 20, 2013), archived at http://perma.cc/4L9J-BN4L [hereinafter Voceros Nacionales].

209. Id.

210. Archibold, supra note 62.

211. Archibold, supra note 62.

212. Archibold, supra note 62.

213. Archibold, supra note 62.

214. OAE Garante de Tregua entre Pandillas de El Salvador, El UnIVERSAL (July 12, 2012), http://www.eluniversal.com.mx/notas/858876.html, archived at http://perma.cc/QW3B-G3V7.

215. Sanz, supra note 59 (translated by the author).

216. Sanz, supra note 59.

217. Pandillas Salvadoreñas Entregan Armas como Parte de una Tregua, supra note 1.

218. Voceros Nacionales, supra note 207. 
truce and its viability in other contexts. Government officials in Guatemala, where gang leaders are said to be considering a truce, initially dismissed the idea of participating ${ }^{219}$ but have softened that position. In January 2013, Guatemalan President, Otto Perez, said his administration was looking for "another way to treat [the gangs]." ${ }^{220}$ While the Guatemalan Barrio 18 has said it is ready to come to the table, Perez noted that the structure of gangs and criminal activity there would make it difficult to replicate the results in El Salvador. ${ }^{221}$

In May 2013, Honduran officials announced that Barrio 18 and the MS-13 had begun a peace process similar to that of their Salvadorian counterparts. ${ }^{222}$ However, the Honduran version of a truce has yet to yield any decrease in the homicide rate. ${ }^{223}$ In fact, murders in the twenty-eight days following the truce were up from the twenty-eight days preceding it. ${ }^{224}$ Honduras's ability to reproduce the results of the truce in El Salvador may be impeded by the less centralized nature of the Honduran gangs and the more disparate causes of violence apart from gang activity. ${ }^{225}$

While Central American countries have expressed interest in the truce, American officials have kept their distance. Mari Carmen Aponte, the American ambassador to El Salvador, said, "[w]e think that, yes, it has reduced crime, but long-range, sustainably, we feel that we have to address the root causes in order to be effective and for any reduction to be sustainable. ${ }^{226}$ Despite this cautionary approach, Aponte reiterated that the embassy supports after-school programs and community policing efforts. ${ }^{227}$ In October 2012, the US Treasury Department designated the MS-13 as a "transnational criminal organization," a status that allows the government to seize its assets and prohibits banks from doing business with the mara. ${ }^{228}$ Salvadorian President Mario Funes and others criticized the decision,

219. Archibold, supra note 62.

220. Hannah Stone \& Miriam Wells, Guatemalan President Seeks 'Alternative' Approach to Gangs, INSIGHT CRIME (Jan. 24, 2013), http://www.insightcrime.org/newsbriefs/guatemalan-president-open-negotiating-gangs, archived at http://perma.cc/B6Q76BTC.

221. Id.

222. James Bargent, Honduran Gangs May Replicate El Salvador Truce, InSight CRIME (May 27, 2013), http://www.insightcrime.org/news-briefs/honduran-gangs-to-replicate-elsalvador-truce, archived at http://perma.cc/78MA-W5PN.

223. James Bargent, Murders in Honduras Rising Despite Gang Truce, InSight CRIME (Aug. 5, 2013), http://www.insightcrime.org/news-briefs/murders-in-honduras-risingdespite-gang-truce, archived at http://perma.cc/S9WW-LPXY.

224. Id.

225. Id.

226. Archibold, supra note 62.

227. Archibold, supra note 62.

228. Jeff Tyler, Obama Administration Targets Latino Street Gang MS-13, MARKETPLACE.ORG (Oct. 11, 2012), http://www.marketplace.org/topics/world/obamaadministration-targets-latino-street-gang-ms-13, archived at $\mathrm{http}: / /$ perma.cc/FHR4-PD7K. 
saying that it overestimated the financial sophistication of the MS-13 by putting it on par with organizations such as the Zetas of Mexico and the Camorra of Italy. ${ }^{229}$ There has been speculation that the classification was an attempt by the US government to controvert the positive image that the MS-13 has gained from the truce and to make it more difficult politically for the Funes administration to support the truce going forward. ${ }^{230}$ Others speculated that this might be a sign of the Obama administration attempting to support the truce by putting more pressure on MS-13 and increasing the Salvadorian government's leverage in negotiations. ${ }^{231}$ Sources inside the US Treasury and Homeland Security Departments denied any connection between the classification and the truce. ${ }^{232}$ They instead insisted that the classification was based on new information of a strong cross-border relationship among the organization's members and that clicas in the United States seek dispute resolution from and send money to the gang's leaders in El Salvador. ${ }^{233}$ Despite the sources' insistence that there was no connection between the truce and the classification of the MS-13 as a transnational criminal organization, the timing remains suspect. ${ }^{234}$ While not indicating hostility to the truce, the government sources indicated that the US will retain the classification even if MS-13 becomes a legitimate organization in El Salvador as a result of negotiations there. ${ }^{235}$

In January 2013, the US State Department also updated its travel warning for El Salvador citing the high level of violence in the country. ${ }^{236}$ While the warning acknowledges the reduction in violent crime due to the truce, it notes that the sustainability of such a decline is unclear. ${ }^{237}$ The

229. Geoffrey Ramsey, El Salvador President: U.S. 'Overestimating' MS-13, InSIGHT CRIME (Oct. 14, 2012), http://www.insightcrime.org/news-briefs/el-salvador-president-usoverestimating-ms-13, archived at http://perma.cc/PK8Q-BNMZ.

230. Id.

231. Hannah Stone, U.S. Ranks MS-13 Alongside Zetas in Gang List, Insight CRIME (Oct. 11, 2012), http://www.insightcrime.org/news-analysis/us-ms13-zetas-transnational.

232. Hannah Stone, U.S. Defends Blacklisting of Salvador Street Gang, Insight CRIME (Nov. 29, 2012), http://www.insightcrime.org/news-analysis/us-defends-blacklisting-ofsalvador-street-gang-ms13, archived at http://perma.cc/6HQP-2Q7B.

233. Id.

234. $I d$.

235. Id.

236. U.S. Dep't. of State, Bureau of Consular Affairs, El Salvador Travel Warning, U.S.

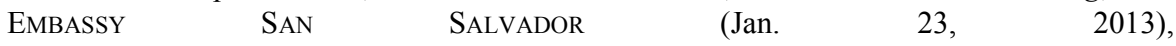
http://sansalvador.usembassy.gov/travel_warning_23jan23.html,_archived at http://perma.cc/LY7Y-CV2M. The travel warning was updated on August 9, 2013, and removed any mention of the truce. U.S. Dep't. of State, Bureau of Consular Affairs, $E l$ Salvador Travel Warning, TRAVEL.STATE.GOV, http://travel.state.gov/content/passports/english/alertswarnings/el-salvador-travelwarning.html (last updated Aug. 9, 2013, archived at http://perma.cc/HJJ7-XLPZ).

237. U.S. Dep't. of State, Bureau of Consular Affairs, El Salvador Travel Warning, U.S. EMBASSY SAN SALVADOR (Jan. 23, 
leaders of the maras as well as the El Salvadorian government responded skeptically, noting that such a warning could have easily been issued in 2010 or 2011 when the violence was at its worst, and calling into question the timing of the United States. ${ }^{238}$

Although the classification of MS-13 by the Treasury Department and the travel warning issued by the State Department are not attempts to directly undermine the truce, they could damage its viability. An important aspect of the re-integration of mareros into Salvadorian society involves jobs and economic development. According to a recent report by Americas Society and Council of the Americas, several multinational corporations, including Microsoft, are engaged in economic development in the region. ${ }^{239}$ Some of these companies have specific jobs programs for ex-mareros. ${ }^{240}$ If the truce is to succeed, additional programs will need to be initiated. ${ }^{241}$ However, the report emphasizes that such efforts will only work if they are also financially beneficial to the corporations. ${ }^{242}$ The signals that the United States has been sending regarding the gangs in El Salvador may make some corporations think twice before relocating jobs to the country, and especially before creating jobs programs for ex-gang members.

In early 2013, then-Security Minister David Munguia Payes and truce-broker Bishop Fabio Colindres went to Washington to request funding to support the efforts of the truce; they visited the offices of Rubén Hinojosa, Mike Honda, Mark Werner, Mathew Salmon, and Javier Becerra and were roundly rejected. ${ }^{243}$ In June, the United States approved $\$ 91.2$ million in funding for security programs in El Salvador; provisions for the truce, however, were conspicuously absent. ${ }^{244}$ This lack of US support leaves questions about the economic feasibility of the truce going forward.

http://sansalvador.usembassy.gov/travel_warning_23jan23.html, archived at http://perma.cc/LY7Y-CV2M

238. Pandilleros Salvadoreños Refutan Advertencia de EU por Violencia, EL NUEVo DiARO (Jan. 28, 2013) http://www.elnuevodiario.com.ni/sucesos/275877-pandillerossalvadorenos-refutan-advertencia-de-eu-violencia, archived at http://perma.cc/K2S-86FE (translated by the author).

239. Elyssa Pachico, How Multinationals Can Help El Salvador's Ex-gang Members, INSigHT CRIME (Jan. 15, 2013), http://www.insightcrime.org/news-analysis/multinationalshelp-salvador-ex-gang-members, archived at http://perma.cc/78EZ-CG6S.

240. Id.

241. Id.

242. Id.

243. Tomás Guevara, Tregua de Pandillas Sin Apoyo de EEUU, ELSALVADOR.COM (Apr. 11 ,

http://www.elsalvador.com/mwedh/nota/nota_completa.asp?idCat=47859\&idArt=7813871, archived at http://perma.cc/5VPX-NBN8.

244. Miriam Wells, US Funds El Salvador Security, Not Gang Truce, InSight CRIME (June 17, 2013), http://www.insightcrime.org/news-briefs/us-funds-el-salvador-security-nottruce, archived at http://perma.cc/ET7U-ZWZZ. 


\section{E. Looking to the Past to Build Solutions Moving Forward: Esquipulas \\ III}

The year 2012 marked the twenty-fifth anniversary of the Esquipulas II Accord, ${ }^{245}$ an agreement among Central American nations to work for peace in the region. Recently, former Guatemalan President Vinicio Cerezo suggested that a new Esquipulas Accord could help combat violence, corruption, and inequality in Central America. ${ }^{246}$ The original Esquipulas moved away from military solutions and sought dialogue and negotiation, democratization and peace. ${ }^{247}$ Such an agreement could address security concerns and alleviate economic inequality and corruption, which contribute to gang violence in the region. Such an agreement could also lay a foundation for further dialogue and economic development that would support the continuation of the peace process in El Salvador.

\section{THE ROLE AND EFFECTS OF INTERNATIONAL LAW ON THE TRUCE IN EL SALVADOR}

While the effects of the violence perpetrated by maras are highly localized, as evidenced by the viability of the "peace zones," the problem of transnational gangs is an international problem. The maras are themselves international in nature spanning all of North America and even into Europe. ${ }^{248}$ The response to maras has also often been regional, multi-lateral, or international. ${ }^{249}$ Additionally, the level of violence and displacement caused by maras, especially in the Northern Triangle, has reached levels that rival the civil wars of the $1970 \mathrm{~s}$ and $1980 \mathrm{~s} .{ }^{250}$ What role does international law play in the viability of the peace process in El Salvador, or other efforts to reduce marero violence moving forward?

\section{A. A Brief History of the Development of International Law and Its Relationship to Violence}

The historical development of international law has to a large extent been precipitated by conflict and war. The origin of the modern framework

245. Acuerdo de Esquipulas II, Aug. 7, 1987, 26 I.L.M. 1166 (1987) archived at http://perma.cc/5K5Y-NJLE.

246. Cynthia J. Arnson, Would Another Peace Accord Help Central America?, WiLson CENTER (Aug. 28, 2012), http://www.wilsoncenter.org/article/latin-american-program-thenews-would-another-peace-accord-help-central-america, archived at http://perma.cc/3PVV$4 \mathrm{~S} 44$.

247. Id.

248. See supra Part II.B.

249. See supra Part IV.A.

250. See McKleskey, supra note 5; Global Burden of ARmed Violence 2011: Lethal ENCOUNTERS, supra note 6. 
is usually traced to the sixteenth century and the Peace of Westphalia (1648), which concluded the Thirty Years War. ${ }^{251}$ The next era in international law was marked by the Paris Peace Conference and the treaties ending World War I, which demarcated an unsuccessful attempt to regulate the use of force through international law. ${ }^{252}$ The subsequent phase of international law was precipitated by both World War II and the UN Charter of 1945 and was characterized by prohibition on the use of force. ${ }^{253}$ This era ended with the fall of the Soviet Union in $1989 .^{254}$

Since 1989 there have been two phases, one lasting from the fall of the USSR until 2001, and the other commencing with the attacks of September $11 .{ }^{255}$ The collapse of the Soviet Union and the subsequent transition to a multipolar world "reinforced the trend toward an expanded role for international institutions in the management and peaceful resolution of conflicts. $" 256$ During this period, there were an abundance of peace agreements, often brokered with UN involvement, which aimed to end internal wars. ${ }^{257}$ The period also saw substantial developments in some of the most high-profile conflicts of the time such as the Israeli-Palestinian dispute, the South African Civil war, and the troubles in Northern Ireland. $^{258}$

A major, overarching phase in contemporary international law was precipitated by the attack on the World Trade Centers on September 11, 2001, and is characterized by a "subjugation of international law to international politics and US hegemony."259 The World Trade Center attacks have affected the international security system, anti-terrorism policy, and conflict-management approaches. ${ }^{260}$ As in Central America with the maras, a traditional approach to counter-terrorism focuses on coercive governmental action and avoidance of dialogue or negotiation with terrorist groups. ${ }^{261}$ These approaches are supported by claims that negotiations

251. Antonio Cassese, International Law 22 (2d ed. 2005).

252. Christine Bell, On the Law of Peace: Peace Agreements \& the Lex PACIFICATORIA 78 (2008).

253. Id.

254. Id. at 78-79.

255. Id. at 79 .

256. L. Sergio Germani \& D.R. Kaarthikeyan, Introduction to PATHWAYS OUT OF Terrorism and Insurgency: The Dynamics of Terrorist Violence and Peace Processes ix (L. Sergio Germani \& D.R. Kaarthikeyan eds., 2005).

257. For example, agreements were reached in Namibia (1988), Western Sahara (1988), Lebanon (1989), Angola (1991 and 1994), South Africa (1991), Cambodia (1991), Mozambique (1992), El Salvador (1992), Ethiopia/Eritrea (1993), Rwanda (1993), Somalia (1993), Afghanistan (1993), Guatemala (1995), Nicaragua (1995), and Liberia (1995). Id. at ix-x.

258. Id. at x.

259. BELL, supra note 252, at 79.

260. Germani \& Kaarthikeyan, supra note 256, at xviii.

261. Germani \& Kaarthikeyan, supra note 256, at xiv. 
between a government and a terrorist group legitimates the terrorists and weakens the moral authority of the State. ${ }^{262}$ Opponents of dialogue also argue that a "peace process" is only a change in tactics on the part of a terrorist organization, rather than a legitimate expression of surrendering the threat of violence, which gives them power. ${ }^{263}$

\section{B. The Development of International Humanitarian Law which Governs Internal Armed Conflict}

International Humanitarian Law (IHL), or "the law of war," was developed to protect people from the consequences of unchecked violence. ${ }^{264}$ However, while this is the goal of IHL, "realistically one can simply require international law to mitigate at least some of the most frightful manifestations of the clash of arms. This is precisely what the rules of warfare endeavor to do."265 Traditional law governing such conflict "was either restated and codified, or developed, at the Brussels Conference of 1874 and at The Hague Peace Conferences of 1899 and 1907."266 The rules embodied in these conventions applied only to inter-State armed conflicts, and fighting by insurgents remained under the rule of domestic criminal law (unless the State granted the insurgents belligerency). ${ }^{267}$ There were a few specific prohibitions of weapons under the rules, and some general principles put into place; for example, belligerents could determine how to enforce compliance with IHL, either via belligerent reprisals or prosecution and punishment under the laws of war. ${ }^{268}$

During World War II, many new classes of combatants emerged, such as resistance movements in the German occupied territories. However, these combatants were not recognized as "lawful combatants" under the Hague codification. ${ }^{269}$ Additionally, as guerrilla warfare spread throughout the colonial world, countries felt that guerrillas, who did not fit within the traditional definition of "combatants," "should be upgraded to the status of lawful combatants subject to conditions." 270 The increase in "wars of the poor," or struggles for national liberation waged by liberation movements and carried out by guerrillas, civil wars (often in less-powerful countries, but backed on either side by world super-powers), and terrorism rendered

262. Germani \& Kaarthikeyan, supra note 256 , at xiv.

263. Germani \& Kaarthikeyan, supra note 256, at xv.

264. See Dawn Steinhoff, Talking to the Enemy: State Legitimacy Concerns with Engaging Non-State Armed Groups, 45 TEX. INT'L L.J. 297 (2009).

265. CASSESE, supra note 251, at 399 (emphasis in original).

266. CASSESE, supra note 251 , at 400.

267. CASSESE, supra note 251, at 401.

268. CASSESE, supra note 251, at 401.

269. CASSESE, supra note 251, at 402.

270. CASSESE, supra note 251, at 402. 
the Hague codification defective and inadequate to address the realities of emerging warfare. ${ }^{271}$

These developments led States to first adopt the Geneva Conventions of 1949 and then later two Protocols in $1977 .{ }^{272}$ While these Conventions and Protocols take into consideration the growing involvement in armed conflict of both civilians and civilian installations, they maintain the basic distinction between combatants and persons who do not take part in hostilities. ${ }^{273}$ Also, after the attacks of September 11, 2001, there was a shift by the United States from addressing "terrorism" under domestic law to utilizing IHL - for example, with how the US defined terrorism for the war waged by the US-led coalition in Afghanistan. ${ }^{274}$ Throughout history, IHL has shifted to encompass new and emerging types of armed conflict; however the contours of marero violence has not as of yet been specifically addressed by IHL.

\section{The Current Legal Regulation of Internal Armed Conflict (IAC)}

Although marero violence is transnational in nature, much of the actual combat is limited to single nations. The law governing internal armed conflict is shaped largely by the inherent conflict between "lawful" governments (whose interest is in regarding rebels as criminals without international status) and the non-State rebels (who want to be internationally recognized). ${ }^{275}$ International law generally used to be conceived of as only applying to State actors and only being made by sSate actors. $^{276}$ However, a more modern approach is that international law regulates the rights and obligations of non-State actors, such as individuals, international bodies, NGOs, and armed groups. ${ }^{277}$ In line with this, "[a]11 rules governing the struggle between the lawful government and insurgents have one main feature in common: they do not grant rebels the status of lawful belligerents. In the eyes of both the government against which they fight and of third-party States, rebels remain criminals infringing domestic penal law. ${ }^{, 278}$ Insurgents only become lawful combatants if the government

271. CASSESE, supra note 251, at 402-03.

272. CASSESE, supra note 251, at 404.

273. CASSESE, supra note 251, at 404.

274. International Humanitarian Law and Terrorism: Questions and Answers, INT'L COMmitte OF THE RED CROSS (Jan. 1 2011), http://www.icrc.org/eng/resources/documents/faq/terrorism-faq-050504.htm, archived at http://perma.cc/8TB2-WEAB.

275. CASSESE, supra note 251, at 429.

276. Anthea Roberts \& Sandesh Sivakumaran, Lawmaking by Nonstate Actors: Engaging Armed Groups in the Creation of International Humanitarian Law, 37 YALE J. INT'L L. 107, 108 (2012).

277. Id.

278. CASSESE, supra note 251, at 429. 
decides to grant them the recognition of belligerency. ${ }^{279}$ Also, rules of IAC typically are focused on the protection of non-combatants only. ${ }^{280}$ Typically, "States prefer to leave fighting substantially unrestricted on the clear assumption that, being militarily stronger than insurgents, they may quell rebellion more easily by remaining untrammeled by law."281 Thus far in El Salvador, this has been the policy toward marero violence and conflict. The Salvadorian government has attempted to address the issue with domestic criminal law reforms (such as Super-Mano Dura) and increased police and military enforcement of such laws.

\section{The Limitations of IHL}

Practically speaking, it is unclear whether IHL as currently applied has a role to play in the regulation of the gang warfare that plagues Central America. The continuity and intensity of the violence in El Salvador and surrounding countries rises to the level of many recognized inter-State conflicts and to the level of the intra-State conflicts that plagued the region in the 1970s and 1980s; the gangs may have reached sufficient levels of sophistication and control of territory in order to meet the definitional standards laid out under some of the IHL standards, but application can be politically difficult. ${ }^{282}$

A major limitation to the application of IHL is that the ultimate determinative question of whether a conflict rises to the level necessary to be governed by IHL must be determined by an international body such as the ICJ, UN Security Council, or the UN Commission on Human Rights. ${ }^{283}$ Due to the nature of international bodies, it is quite possible that a given conflict may never arrive in front of one of these decision makers, or that it may take a long time. However, until an international body determines the application of one of these definitions, the State has the power to determine the nature of the conflict. ${ }^{284}$ Finally,

[o]ver the years mankind has witnessed steady progress in the sophistication, the devastating effects, and the cruelty of weapons and methods of combat. International legal control of warfare has kept pace with developments in organized armed violence only to a limited extent. States and, in particular, major military Powers have not accepted sweeping restraints, with the consequence that this body of

279. CASSESE, supra note 251, at 429.

280. CASSESE, supra note 251, at 430.

281. CASSESE, supra note 251 , at 430.

282. See Steinhoff, supra note 264, at 312.

283. Steinhoff, supra note 264, at 313.

284. Steinhoff, supra note 264, at 313. 
law is beset with deficiencies, loopholes, and ambiguity. ${ }^{285}$

It is in large part because of these ambiguities and loopholes, along with States' resistance to the application of international law and preference for domestic law, that application of IHL in its current form to the marero violence is unlikely.

\section{E. International Human Rights Law's Role in the Conflict}

El Salvador is bound by several International Human Rights treaties, including the International Convention on Civil and Political Rights (ICCPR) ${ }^{286}$ The ICCPR obligates State Parties to undertake to ensure the rights contained in the covenant. ${ }^{287}$ Under article 2,

the positive obligations on States Parties to ensure Covenant rights will only be fully discharged if individuals are protected by the State, not just against violations of Covenant rights by its agents, but also against acts committed by private persons or entities that would impair the enjoyment of Covenant rights. ${ }^{288}$

Several of the articles of the ICCPR might be implicated by the violent situation in El Salvador. Article 6, for example, states in relevant part that "[e]very human being has the inherent right to life. This right shall be protected by law. No one shall be arbitrarily deprived of his life." 289 This provision, combined with article 2, obliges El Salvador to prohibit the action of private citizens, such as mareros, from arbitrarily depriving anyone of life. Prior to the gang-truce, El Salvador aimed to meet its obligation through traditional suppression methods mixed with some rehabilitative measures. However, it could be argued that now that the truce has had substantial success in reducing arbitrary deprivation of life, El Salvador could not withdraw from the peace process without breaching its obligations under the ICCPR. However, practically speaking this is unlikely. As is the case with IHL, the enforcement of non-criminal-IHRL is

285. CASSESE, supra note 251, at 434.

286. Status of the International Convention on Civil and Political Rights, UN TREATY COLLECTION, http://treaties.un.org/Pages/ViewDetails.aspx?src=TREATY\&mtdsg_no=IV4\&chapter=4\&lang=en (last visited Nov. 13, 2013, archived at http://perma.cc/7B5Z-L62N) (El Salvador ratified the ICCPR on Nov. 30, 1979, without reservation).

287. International Covenant on Civil and Political Rights art. 2, Dec. 16, 1966, 999 U.N.T.S. 171 [hereinafter ICCPR].

288. Human Rights Committee, General Comment No. 31 [80] Nature of the General Legal Obligation Imposed on States Parties to the Covenant, CCPR/C/21/Rev.1/Add. 13 (May 26, 2004, archived at http://perma.cc/WYP9-JCXN).

289. ICCPR, supra note 287, art. 6. 
largely executed by States, and it is unlikely that these States will go so far as to hold El Salvador in violation of its obligations under the ICCPR because of El Salvador's choice of crime reduction strategy for fear of future infringements on each State's own sovereignty in the area of domestic criminal law. The other problem with IHRL with respect to the marero conflict in El Salvador is that only State Parties are bound by IHRL agreements, which neither bind the actions of the mareros nor create alternate strategies for reducing violence.

\section{F. How IHL \& IHRL Inform the Truce in El Salvador}

Although IHL and IHRL are unlikely to provide any immediate protection from violence or relief for the people of El Salvador, they are still likely to perform an important function in the peace process. The laws that make up the law of armed conflict and human rights law perform an important normative and moral function: "[T]hey serve as a moral and political yardstick by which public opinion and non-governmental groups and associations can appraise if, and to what extent, States misbehave."290 Therefore IHL and IHRL have an important normative role to play in the peace process in El Salvador. The overall message of IHL is clear: "Regardless of the point of view, humanitarianism should be the focus . . . To maximize humanitarian goals, legitimacy should not be a concern when engaging a group." 291 Arguably, norms accepted as part of IHL and IHRL are a group of norms which can form a basis for negotiation regarding particular forms of violence and recruiting as the peace process moves forward.

\section{G. A Developing Body of Law Beyond Current International Law}

International law has shifted and changed over time to keep pace with the changing nature of armed conflict. As an increasing amount of sustained armed conflict is related to criminal organizations, it is possible that States will become more open to the idea of creating humanitarian frameworks governing such conflicts. This includes an emerging "Law of Peace."

Even if a conflict is not subject to IHL, the parties are able to apply all or part of the Conventions to the conflict by agreement. ${ }^{292}$ The Geneva Convention's safeguards for civilians in all conflicts can be rendered useless through the non-compliance of armed groups, putting civilians at highest risk. ${ }^{293}$ Also, "[s]ince the main victims of twenty-first century conflicts are civilians, it should not be a matter of whether the actor

290. CASSESE, supra note 251, at 434.

291. Steinhoff, supra note 264 , at 320.

292. Steinhoff, supra note 264 , at 300.

293. Steinhoff, supra note 264 , at 303. 
agreeing to adhere to IHL norms is a state or armed group." ${ }^{294}$ The former UN Secretary-General Kofi Annan repeatedly encouraged negotiations with armed groups to protect civilians and provide access to them during armed conflicts, stating:

Whereas Governments are sometimes concerned that . . . engagements might legitimize armed groups, these concerns must be balanced against the urgent need for humanitarian action. It is the obligation to preserve the physical integrity of each and every civilian within their jurisdiction, regardless of gender, ethnicity, religion or political conviction, that should guide Governments in exercising their sovereign responsibility. ${ }^{295}$

Therefore, in spite of the lack of application of IHL, a State may choose to nevertheless engage an armed group in direct peace negotiations in order to advance humanitarian aims, like El Salvador chose to do in the case of the maras.

International Humanitarian Law, International Human Rights Law, and domestic criminal law tend to all work to regulate and restrict violence. ${ }^{296}$ However, there is no developed body of law that outlines the establishing of peace out of violent conflict. ${ }^{297}$ Christine Bell, in her book On the Law of Peace, argues "the practice of negotiating peace agreements is producing a new law of the peace maker-or lex pacificatoria. ${ }^{, 298}$ Bell examines contemporary peace agreements and distills theories about the form and function of contemporary peace agreements. She argues for an emerging enforceable law of peace that would apply to peace processes regardless of the application of IHL. ${ }^{299}$

Of particular relevance to the peace process in El Salvador, Bell restates the norms established by contemporary peace agreements regarding transitional justice. ${ }^{300}$ This statement of the new law of transitional justice is as follows:

(1) Blanket amnesties that cover serious international crimes are not permitted.

294. Steinhoff, supra note 264, at 303.

295. The Secretary-General, Reports of the Secretary-General on the Protection of Civilians in Armed Conflict, delivered to the Security Council, para. 20, U.N. Doc. $\mathrm{S} / 2001 / 331$ (Mar. 30, 2001), quoted in id. at 303-04.

296. BELL, supra note 252, at 5.

297. BELL, supra note 252, at 5.

298. BELL, supra note 252 , at 5.

299. BeLL, supra note 252, at 5.

300. BELL, supra note 252 , at 40 . 
(2) Some amnesty is required to facilitate the release, demilitarization and demobilization of conflict-related prisoners and detainees.

(3) The normative commitment to accountability should be married with the goal of sustaining the ceasefire and developing the constitutional commitments at the heart of the peace agreement. This can be achieved by creative design based around the following mechanisms:

(a) quasi-legal mechanisms which deliver forms of accountability other than criminal law processes with prosecution, such as Truth Commissions;

(b) a bifurcated approach whereby international criminal processes for the most serious offenders coupled with creatively designed local mechanisms, including forms of amnesty for those further down the chain of responsibility, aim at a range of goals such as accountability, demobilization and reconciliation.

(4) Should any party evidence lack of commitment to the peace agreement, and in particular return to violence, any compromise on criminal justice is voidable and reversible through the use of international criminal justice. ${ }^{301}$

This type of criminal amnesty seems unlikely in the current climate in El Salvador, especially given President Funes's recent rejection of the mareros proposal to repeal the new anti-mara law in exchange for disarmament in ten cities across El Salvador. ${ }^{302}$ However, there are two things to consider. First, Funes is amenable to amending the anti-mara laws. ${ }^{303}$ Second, it is important to recall that the mareros are not seeking to become a legitimate political party. As former congressman Raul Mijango said to ElFaro.com:

What is victory for them? And when I began to reflect on this with them, it turns out that their war is about subsistence, about survival. . . . [T] hey are clear in telling you, and they have highlighted this for me several times: Don't confuse things, we are not guerrilla, we are a gang. And what do they mean by this? That they don't aspire to political power. . . . They are simply a social group that feels that society has denied them every opportunity to develop themselves and they have had to come together to

301. BELL, supra note 252, at 240.

302. See supra notes 166-67 and accompanying text.

303. See supra note 168 and accompanying text. 
survive. The big goal is to survive! Which means, this is a war with no end. And if there is no end, what is the cost to the country? The final reflection is: Why does this war exist? This will only have a solution if we look at the root causes. $^{304}$

In spite of Funes's offer to amend current law, and the mareros' distinct goals, the participants in the peace process will likely encounter significant challenges negotiating any changes in the criminal laws regarding the maras because of the stringent opposition domestically and internationally to negotiating with criminals, and the inherent distrust of the mareros. However, while the maras currently are not collectively seeking release from jail, or amnesty for their previous crimes, they are seeking legal reforms that would make their survival individually and as an institution more sustainable without criminal activity. It will be interesting to see how these interests play out in the transitional phase of the peace process in El Salvador.

\section{H. El Salvador's Conflicting Obligations under International Law}

One reason that the Funes Government may be resistant to altering the anti-mara laws in El Salvador is due to a conflict in the country's obligations under international treaties and the current peace negotiations. According to article 144 of El Salvador's constitution, international treaties are incorporated into El Salvador's domestic law, and in case of conflict between domestic law and a treaty, the latter prevails. ${ }^{305}$ This creates some competing obligations that apply to the current negotiations with the gangs in El Salvador.

\section{UNODC Convention against Transnational Criminal Organizations}

El Salvador is party to the United Nations Convention against Transnational Organized Crime. ${ }^{306}$ This Convention addresses what State

\footnotetext{
304. Mónica Navoa, El Salvador's Historic Truce May Show Pathway to Peace in the US, COlorlines (June 25, 2012, 9:58 AM), $\mathrm{http} / / /$ colorlines.com/archives/2012/06/gang_truce_el_salvador.html, archived at http://perma.cc/7N8L-SJ6G.

305. Constitution De la Republica de El Salvador, Articulo 144, archived at http://perma.cc/FRG8-94ZL.

306. Fifth Session of the Conference of the Parties, Vienna, Austria, Oct. 18-22, 2010, Status of Ratification of the United Nations Convention against Transnational Organized Crime and the Protocols

thereto and Notifications, Declarations and Reservations thereto as of 29 September 2010, U.N. Doc. CTOC/COP/2010/CRP.4, archived at http://perma.cc/FDW8-BT9D (El Salvador
} 
Parties shall do to address transnational organized criminal organizations, including defining certain crimes to be incorporated into domestic criminal codes, and providing measures concerning international cooperation, money laundering prevention, and jurisdictional issues. ${ }^{307}$

The activities of the mareros in El Salvador almost certainly come under the definitions and scope of the Convention, at least by the text of the Convention alone. Article 2 defines an "organized criminal group" as a "structured group of three or more persons, existing for a period of time and acting in concert with the aim of committing one or more serious crimes or offences established in accordance with this Convention, in order to obtain, directly or indirectly, a financial or other material benefit." ${ }^{\prime 308}$ The maras have large memberships, and have existed for decades. They act in concert to commit "serious crimes" (defined by article 2 as "conduct constituting an offence punishable by a maximum deprivation of liberty of at least four years or a more serious penalty" $)^{309}$ in order to obtain material benefits. They also meet the relatively loose definition of a "structured group," which does not require sophisticated levels of organization, but rather need only be "a group that is not randomly formed for the immediate commission of an offence and that does not need to have formally defined roles for its members, continuity of its membership or a developed structure."310

To be governed by the Convention, an offense must be "transnational in nature," which means that:

(a) It is committed in more than one State; (b) It is committed in one State but a substantial part of its preparation, planning, direction or control takes place in another State; (c) It is committed in one State but involves an organized criminal group that engages in criminal activities in more than one State; or (d) It is committed in one State but has substantial effects in another State. ${ }^{311}$

Maras like MS-13 and Barrio 18 will always fit this definition because of their strong presence in other North American countries.

Under article 5 of the Convention, State Parties are obligated to enact laws criminalizing participation in organized criminal groups. ${ }^{312}$ Article 5, in relevant part, reads:

ratified the Convention on March 18, 2004).

307. See generally United Nations Convention Against Transnational Organized Crime, Nov. 15, 2000, 2225 U.N.T.S. 209, archived at http://perma.cc/YS38-M6PR.

308. Id. art. 2 .

309. Id.

310. Id.

311. Id. art. 3 (emphasis added).

312. Id. art. 5. 
1. Each State Party shall adopt such legislative and other measures as may be necessary to establish as criminal offences, when committed intentionally:

(a) Either or both of the following as criminal offences distinct from those involving the attempt or completion of the criminal activity:

(i) Agreeing with one or more other persons to commit a serious crime for a purpose relating directly or indirectly to the obtaining of a financial or other material benefit and, where required by domestic law, involving an act undertaken by one of the participants in furtherance of the agreement or involving an organized criminal group;

(ii) Conduct by a person who, with knowledge of either the aim and general criminal activity of an organized criminal group or its intention to commit the crimes in question, takes an active part in:

a. Criminal activities of the organized criminal group;

b. Other activities of the organized criminal group in the knowledge that his or her participation will contribute to the achievement of the above-described criminal aim . . . 313

This article of the Convention functions to criminalize membership in the maras because it is widely known that the maras have a criminal "aim" (yet, perhaps, not a criminal "end") and it would be difficult to deny that one had knowledge of the "aim" of the maras. The Convention does not require that the individual participate in the criminal activities in order to be subject to criminal penalty, but rather that one "actively participate in other activities of the organized criminal group" with knowledge that it will advance the organization's criminal aim. The scheme laid out under the Convention essentially criminalizes joining a mara and actively participating in a wide range of non-criminal activities, as long as one knows that the participation will advance the group's criminal acts. This becomes important as repeal of the criminalization of gang membership has become a lynchpin of the negotiations.

Adding complication, some have argued that those acting in support of the truce are in violation of the domestic law, which criminalizes gang membership. ${ }^{314}$ Enacted in September 2010, the law which outlaws maras,

313. Id.

314. Hannah Stone, Why El Salvador's Gang Truce is Illegal, and Why it Matters, INSigHT CRIME (Mar. 27, 2013), http://www.insightcrime.org/news-analysis/el-salvadorgang-truce-illegal, archived at http://perma.cc/L2EU-6GJF; Jose Luis Sanz, La Tregua entre Pandillas o el Estado en Conflicto con la Ley, EL FARO (Mar. 4, 2013), http://www.elfaro.net/es/201303/noticias/11225/, archived at http://perma.cc/S8JW-AGRU. 
pandillas, groups, associations, and organizations of a criminal nature makes individuals who participate in otherwise legal acts criminally liable if the acts provide support to the gang. ${ }^{315}$ Some in the government have acknowledged that this law is an impediment to negotiations because the government actors risked criminal liability if they provided jobs, financing, or neighborhood improvements as part of negotiations. ${ }^{316}$ Former Vice Minister Moreno said of the law that "[y]es, it is an obstacle[.] When it was passed it didn't establish an exception for rehabilitation. We need to further develop this discussion." 317

As the peace process continues, it seems that the gangs will continue to demand repeal of laws criminalizing gang membership and support. If El Salvador repealed such laws, it would likely be in breach of its obligations under the Convention against Transnational Organized Crime. If the peace process is to move forward, these conflicts between El Salvador's obligations under international treaties and its domestic laws which aim at decreasing transnational crime and the demands of the process of negotiation with the maras must be resolved. These conflicts will shape the direction of the peace process and may contribute to its ultimate success or failure.

\section{CONCLUSIONS-HOW CAN THE INTERNATIONAL COMMUNITY AND INTERNATIONAL LAW SHIFT TO SUPPORT THE PEACE PROCESS IN EL SALVADOR?}

The violent marero conflicts in El Salvador and other countries, especially in the Northern Triangle, have reached an intensity rivaling the civil wars in that region. These conflicts have elicited a variety of responses domestically (in the form of mano dura and mano amiga policies), internationally, regionally, and multilaterally in the form of military and police support, funding, and strategy agreements. In March 2012, the Government of El Salvador, the OAS, and civil society actors within El Salvador sought to engage the maras in negotiations to end the violence in the country. In spite of some setbacks, the truce has been honored for over a year, and the peace process has developed into a second phase, establishing "peace zones," which will be free of all criminal activity. These negotiations have led to notable decreases in the homicide rate in El Salvador. Now, Honduras has enacted a similar truce and Guatemala is examining the possibility of "alternative approaches" to dealing with gang violence. However, the United States and many inside El Salvador have

315. La Ley de Proscripción de Maras, Pandillas, Agrupaciones, Asociaciones y Organizaciones de Naturaleza Criminal, Dicrito 458, art. 2, Diario Oficial 169, Tomo 388, Sept. 10, 2010 (E1 Salv.), archived at http://perma.cc/FRF8-RL7T.

316. Sanz, supra note 314.

317. Sanz, supra note 314 (translated by the author). 
been skeptical of the truce. Although the United States has not directly sought to undermine the truce, the classification of MS-13 by the US Treasury Department and the US State Department's January 2013 travel warning both were seen by the maras and by the Salvadorian government as backhanded criticism of the truce. Within El Salvador there are claims that violence has not decreased, but is being hidden by the maras, and that the maras are not actually seeking peace, but are using the truce as a platform to legitimize themselves, reduce police scrutiny, and reorganize and become stronger.

The peace process in El Salvador has the potential to serve the same humanitarian goals that have been the impetus for the development of international law since the development of the international community. These humanitarian goals, embodied in the norms of IHL and IHRL, can be achieved through direct negotiations with armed groups like the maras. However, concerns among States in the international community have disincentivized direct negotiation with armed groups for fear of legitimizing them or giving them international personality. While legitimizing armed groups is a concern, the political and legal effects of such legitimacy are dwarfed by the immense humanitarian benefits of successful negotiation, especially in the case of El Salvador where the results have been so drastic.

In spite of these disincentives, the Funes administration and the Secretary General of the OAS have been willing to engage with armed maras because they recognize the important benefits for the people of El Salvador in reducing violence, crime, and extortion. However, there are international legal and political pressures and mounting domestic pressures that restrict the flexibility of the government in these negotiations. The UNODC Convention Against Transnational Crime Organizations and its companion laws in El Salvador are proving to be substantial impediments to peace in El Salvador. It is important that the international community begin to develop a framework that serves the longstanding goals of international law while honoring sovereignty and the rule of law which will support engagement with armed groups like the maras of El Salvador.

Because of the transnational nature of the maras, it is crucial that other countries in the region, even if they choose not to negotiate with mareros domestically, do not act to undermine the peace process in El Salvador. Although the United States has not directly acted to undermine the truce, officials have said that the government will continue to sanction MS-13 even if they become a legitimate political organization in El Salvador. This would most certainly undermine the sustainability of peace processes in El Salvador and beyond, which will depend to some extent on the availability of jobs and economic development in the region. This development will be difficult to come by if the largest economic player in the region continues to send signals of its skepticism regarding the viability of peace. To this end, it may be beneficial to seek a regional agreement on a framework that countries in the region are dedicated to the goal of peace 
similar to Esquipulas I and II-the agreements which presented a framework for an end to the wars in Central American in the 1990s. In Esquipulas II, the countries of Central America agreed to "the cessation of hostilities" and promised "to take all necessary action to achieve an effective cessation to the fire within a constitutional framework." ${ }^{318}$ While such agreements do not end internal conflicts, they do provide a basis on which the States involved in the conflicts agree to seek peace rather than impede it, an important step along the road to a sustainable and lasting peace. Without such cooperation and support the peace process in El Salvador cannot survive.

\footnotetext{
318. Acuerdo de Esquipulas II, supra note 245.
} 